\title{
Host-Parasite Interaction in Sarcoptes scabiei Infestation in Porcine Model with a Preliminary Note on Its Genetic Lineage from India
}

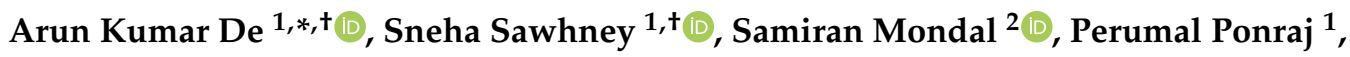 \\ Sanjay Kumar Ravi ${ }^{1}$, Gopal Sarkar ${ }^{2} \mathbb{D}$, Santanu Banik ${ }^{3} \mathbb{D}$, Dhruba Malakar ${ }^{4}$ (D), \\ Kangayan Muniswamy ${ }^{1}$, Ashish Kumar ${ }^{5}{ }^{1}$, Arvind Kumar Tripathi ${ }^{1}$, Asit Kumar Bera ${ }^{6}$ \\ and Debasis Bhattacharya ${ }^{1}$ (D) \\ 1 Animal Science Division, ICAR-Central Island Agricultural Research Institute, Port Blair 744101, India; \\ snehasawhney88@gmail.com (S.S.); perumalponraj@gmail.com (P.P.); skravivet@gmail.com (S.K.R.); \\ swamy02_vet@yahoo.co.in (K.M.); akt9@rediffmail.com (A.K.T.); debasis63@rediffmail.com (D.B.) \\ 2 Department of Veterinary Pathology, West Bengal University of Animal and Fishery Sciences, \\ Kolkata 700037, India; vetsamiran@gmail.com (S.M.); gsarkar999@gmail.com (G.S.) \\ 3 Department of Animal Genetics and Breeding, ICAR-National Research Centre on Pig, \\ Guwahati 781131, India; sbanik2000@gmail.com \\ 4 Animal Biotechnology Centre, National Dairy Research Institute, Karnal 132001, India; \\ dhrubamalakar@gmail.com \\ $5 \quad$ CTARA, IIT Bombay, Mumbai 400076, India; ashish7@iitb.ac.in \\ 6 Reservoir and Wetland Fisheries Division, ICAR-Central Inland Fishery Research Institute, Barrackpore, \\ Kolkata 700120, India; asitmed2000@yahoo.com \\ * Correspondence: biotech.cari@gmail.com; Tel.: +91-967-951-5260 \\ + These authors contributed equally to this paper.
}

Received: 4 November 2020; Accepted: 1 December 2020; Published: 7 December 2020

Simple Summary: Scabies or mange caused by Sarcoptess cabiei is the latest addition of WHO's list oftropical neglected diseases. It causes severe itching to the host. It has a wide host range including humans, farm animals, companion animals, and wild animals. It is anemerging/re-emerging disease with high prevalence in underdeveloped and developing countries. The disease has zoonotic importance and is of significant public health concern as cross-transmission or species jumping is very common. To date, fifteen Sarcoptes varieties have been reported as per host origin. Differential diagnosis at variety level is very crucial for epidemiological study and scratching future eradication program of the disease. As morphotaxonomy fails to differentiate varieties, use of molecular markers is crucial. Moreover, it is very important to understand the host-parasite interaction at the systemic level for a better understanding on the pathogenicity of the disease. Here, we report the genetic characterization of $S$. scabiei from India and host-parasite interaction in a porcine model.

Abstract: The burrowing mite Sarcoptes scabiei causes scabies in humans or mange in animals.
It infests a wide range of mammalian species including livestock, companion animals, wild animals,
and humans. Differential diagnosis of Sarcoptes varieties is key for epidemiological studies and
for formulation of an eradication program. Host-parasite interaction at the systemic level is
very important to understand the pathogenicity of the mite. This communication deals with the
preliminary report on the genetic characterization of $S$. scabiei from India. Moreover, the effect of
S. scabiei infestation on host physiology with special emphasis on serum biochemical parameters,
lipid profile, oxidant/antioxidant balance, stress parameters, and immune responses were evaluated in
a porcine model. Cytochrome $C$ oxidase 1 and voltage-sensitive sodium channel based phylogenetic
study could distinguish human and animals isolates but could not distinguish host or geographical
specific isolates belonging to animal origin. An absence of host-specific cluster among animal
isolates argues against the hypothesis of delineating $S$. scabiei as per host origin. Elevated levels of 
markers of liver function such as albumin, AST, ALT, ALP, and LDH in infested animals indicated impaired liver function in infested animals. S. scabiei infestation induced atherogenic dyslipidemia indicated by elevated levels of total cholesterol, low-density lipoprotein cholesterol and triglycerides, and a decreased level of high-density lipoprotein cholesterol. Oxidative stress in infested animals was indicated by a high level of nitric oxide and serum MDA as oxidative stress markers and low antioxidant capacity. S. scabiei triggered stress response and elevated levels of serum cortisol and heat shock proteins were recorded in infested animals. S. scabiei infestation increased the serum concentration of immunoglobulins and was associated with up-regulation of IL-2, IFN- $\gamma$, IL-1 $\beta$, and IL-4 indicating both Th1 and Th2 response. The results of the study will be helpful for a better understanding of host-parasite interaction at the systemic level in crusted scabies in pigs.

Keywords: Sarcoptes scabiei; host-parasite interaction; molecular characterization; lipid profile; antioxidant

\section{Introduction}

Scabies in human, or mange in animals, caused by the burrowing mite Sarcoptes scabiei, is a neglected tropical infectious disease and is prevalent worldwide especially in developing and under-developed countries [1,2]. It infests more than 100 mammalian species including livestock, companion animals, wild animals, and humans [3-5]. Mange is considered as an emerging/re-emerging infectious disease and imparts huge economic loss to the livestock industry due to devastating morbidity and reduced production [3,5]. It is regarded as a significant public health concern in underdeveloped and developing countries as it is frequently associated with bacterial super-infection, which may sometimes be fatal especially in children if not treated in time [6]. Worldwide, around 300 million people are estimated to be infested with scabies every year [7] and its prevalence among children in Africa and indigenous communities of Northern Australia is astoundingly high ranging from 25 to 80\% [8-10]. Scabies is broadly categorized into two forms, ordinary scabies with low mite burden $(<20)$ or crusted scabies with high mite load and hyper-keratosis of the skin [11]. The mite S. scabiei causes inflammation of the skin which is associated with an exudate which forms crusts on the surface [12].

Controversy and conflicting opinion exist regarding speciation of S. scabiei; some believe that S. scabiei infesting different hosts are monospecific whereas others claim that they belong to different species or subspecies $[13,14]$. Currently, there is a broad consensus that the species Sarcoptes is divided into different varieties as per its host origin $[13,15]$ and to date, more than 15 diverse varieties have been reported [2,16]. Of recent, this hypothesis has been challenged as cross-transmission or species jumping is very common in some varieties [17]. Therefore, differential diagnosis of Sarcoptes varieties is crucial for epidemiological studies [18] and formulating eradication strategies [15]. Morphotaxonomy has failed to differentiate between varieties as they share similar morphology [19]. Molecular diagnosis based on ribosomal DNA spacer region has been unsuccessful in identifying S. scabiei to the host level [20] and immunological diagnosis is also very challenging as different varieties produce immunologically identical proteins [21]. Recently, mitochondrial cytochrome oxidase 1 (COX1) based marker has shown promising results in varieties level confirmation of $S$. scabiei infestation. No information on genetic characterization or molecular confirmation in S. scabiei is available from India. The present study seems to be the first report on the genetic characterization of $S$. scabiei from India.

Sarcoptic mange is a very common ectoparasite disease in pigs [22,23]. It affects growth rate and reproductive performance in pigs and increases piglet mortality [24-26] leading to significant economic loss to the swine industry. A rare probability of zoonotic potential of S. scabiei var suis cannot be ignored [27]; it may be transmitted to affect a variety of different animal host species as well as pig handlers $[28,29]$ causing severe itching. As pigs in semi-intensive systems in developing and under-developed countries are generally reared by tribes who keep a close association with the animals, 
there is a chance of transmission to humans, especially children and immunocompromised adults [4]. Moreover, in developed countries, pigs have been kept as pets which can transmit the disease to humans. Sarcoptic mange is a very common problem in the pig rearing regions of India, especially Northeast and Eastern parts of India [30]. In the Andaman and Nicobar Islands, Nicobari pigs are reared by Nicobarese tribal people and close association between tribal people and pigs is observed.

S. scabiei modulates host immunity, inflammatory, and complement reactions in order to be established to the host skin [31-33]. S. scabiei infestation triggers multiple reactions including allergic reactions, inflammation, innate immune reactions, and activation of immune components in the skin [34]. The salivary solutions of burrowing mites contain different bioactive compounds with potential to influence host physiological functions [35]. Mites are reported to influence the cytokine and chemokine secretion from keratinocytes and dermal fibroblasts [31,33] and disturb the balance between Th1 and Th2 immune responses [36]. In addition, S. scabiei has been reported to disturb the antioxidant defense system in mammalian hosts [37,38]. However, the studies were mostly in vitro using skin equivalents [31]. Little is known about the host parasite interaction in S. scabiei infestation at the systemic level. Therefore, the study aims at genetic characterization of S. scabiei isolated from Nicobari pigs and a better understanding on host parasite interactions with special emphasis on serum biochemical parameters, lipid profile, oxidant/antioxidant balance, stress parameters, and immune responses.

\section{Materials and Methods}

\subsection{Ethics Approval}

This research has been approved by the Institute Animal Ethics Committee (IAEC) of ICAR-Central Island Agricultural Research Institute (ICAR-CIARI), Port Blair, Andaman and Nicobar Islands, India on 12 January 2020 and the ethical approved project identification code is 'ICAR-CIARI/AS/AICRP-Pig/IAEC/4960 dated 12 January 2020'. All the methods were performed in accordance with the relevant national guidelines and regulations.

\subsection{Study Area and the Animals}

The study was conducted on Nicobari pigs maintained at the institute pig farm of ICAR-CIARI $\left(11.6060^{\circ} \mathrm{N}, 92.7058^{\circ} \mathrm{E}\right)$. Sarcoptic mange infestation in pigs was identified during a routine visit to the farm. Fifteen S. scabiei-infested animals (5-6 months old, 8 male and 7 female) participated in the present study. Ten healthy animals (5-6 months old, 5 male and 5 female) were treated as control. Absence of $S$. scabiei infestation in control animals was confirmed by dermatological and microscopic examination. All the animals were examined for presence of fleas, lice, ticks, or any other ectoparasite, and animals negative for these were only considered in the study. Coproscopic examination for light and heavy eggs [12] confirmed that the animals were free from gastrointestinal parasites and the animals were serologically negative for classical swine fever which is endemic to the Andaman and Nicobar Islands. Both control and infested animals were maintained in 12-h light-dark cycle on concrete floor in separate pens to avoid chance of transmission of sarcoptic mange and fed with a commercial diet containing $18 \%$ crude protein, $2 \%$ crude fat, $6 \%$ crude fiber, $4 \%$ acid insoluble ash and $10 \%$ moisture. The animals were offered water ad libitum.

\subsection{Collection and Processing of Clinical Samples for Microscopic Analysis}

Skin scrapings were collected from the infested Nicobari pigs using surgical blades. Mineral oil was applied on the surgical blades and scrapings were taken from the crusted area of skin till little blood appeared. Collected material was boiled in $10 \%$ sodium hydroxide $(\mathrm{NaOH})(w / v)$ solution to dissolve the keratinized tissue and was centrifuged at $500 \times g$ for five minutes and the sediment was examined under $100 \times$ magnification in a light microscope (Trinocular Compound Microscope, Quasmo, 
Ambala, Haryana, India 180129/53268). Photographs of different stages of mite and eggs present were taken at $400 \times$ magnification.

\subsection{DNA Extraction}

DNA from skin scrapings was isolated by a commercial kit (DNeasy Blood and Tissue kit, Cat. No. 69504, Qiagen, Hilden, Germany). Briefly, $25 \mathrm{mg}$ of skin scrapping was ground in lysis buffer using a sterile pestle and motor. For cell lysis, proteinase $\mathrm{K}$ was added to the ground scrapings and it was incubated at $56{ }^{\circ} \mathrm{C}$ in a water bath overnight. The completely lysed samples were used for genomic DNA extraction as per protocol recommended by the manufacturer. The DNA samples were kept at $-80^{\circ} \mathrm{C}$ until further use.

\subsection{Amplification and Sequencing of Cytochrome C Oxidase Subunit 1 (COX1) and Voltage Sensitive Sodium} Channel (VSSC) Gene Segments

For molecular identification and characterization of the mite, two gene segments namely COX1 and VSCC were chosen [34]. COX1 and VSCC gene fragments were amplified using primers described earlier by Erster et al. [34]. The PCR was performed in Thermocycler (Eppendorf, Hamburg, Germany) with the cycling conditions mentioned previously [34]. The amplicons were purified using a commercial kit (MinElute PCR Purification Kit, Cat. No. 28004, Qiagen, Hilden, Germany) as per manufacturer's protocol and sequence information was generated by dideoxy fingerprinting.

\subsection{Sequence Analysis}

Representative COX1 and VSSC sequences of S. scabiei from different hosts distributed in different geographical regions were retrieved from GenBank (www.ncbi.nlm.nih.gov) and a summary of the information has been depicted in Table S1. Alignment of the sequences was done by ClustalW [39] in MEGAX [40]. Phylogenetic tree was constructed in MEGAX using Maximum Likelihood method and Tamura-Nei model [41]. The reliability of the tree was judged by 1000 bootstrap replications. For phylogenetic tree construction, we trimmed extra nucleotides from our sequences and GenBank retrieved sequences to make a homogeneous length of $193 \mathrm{bp}$ for COX1 and $436 \mathrm{bp}$ for VSSC. Evolutionary relationship among different sequences was deduced by median-joining networks constructed in Network v 10 with default settings [42].

\subsection{Estimation of Biochemical Parameters}

Commercially available kits (TBL, Solan, India) were used for estimation of serum biochemical parameters such as total protein, albumin, globulin, glucose, aspartate aminotransferase (AST), alanine aminotransferase (ALT), alkaline phosphatase (ALP), lactate dehydrogenase (LDH) and creatine kinase $(\mathrm{CK})$. The parameters were assessed in an automated clinical chemistry analyzer (Transasia Biomedical Limited, Mumbai, India). The reference values of the parameters are presented in Table S2.

\subsection{Estimation of Oxidative Stress Parameters}

To investigate the oxidant/antioxidant balance in serum following S. scabiei infestation, the markers of oxidative stress such as serum level of total nitric oxide (NO), total serum antioxidant activity, malonyldialdehyde (MDA) concentration, as well as the levels of antioxidant enzymes; superoxide dismutase (SOD), glutathione-S-transferase (GSH), catalase were determined and compared to control animals.

NO level was evaluated by a commercial kit (EZAssay ${ }^{\mathrm{TM}}$ Nitric Oxide Estimation kit, HiMedia Laboratories Pvt. Ltd., Nashik, India) according to the manufacturer's instructions. The principle of the assay is the reduction of $\mathrm{NO}_{3}$ which was then converted to a blue-colored azo compound. The absorbance was recorded at $630 \mathrm{~nm}$. 
Antioxidant activity in serum was estimated by a colorimetric kit (EZAssay ${ }^{\mathrm{TM}}$ Antioxidant Activity Estimation kit, HiMedia Laboratories Pvt. Ltd., Nashik, India) following the protocol recommended by the manufacturer.

Level of lipid peroxidation was measured by measurement of malonyldialdehyde (MDA). Levels of MDA in serum were measured by a commercial colorimetric based assay kit (EZAssay ${ }^{\mathrm{TM}} \mathrm{TBARS}^{\mathrm{T}}$ estimation kit for lipid peroxidation, HiMedia Laboratories Pvt. Ltd., Nashik, India).

Serum levels of catalase, superoxide dismutase, glutathione-S-transferase were measured by ELISA based methodology using catalase assay kit, superoxide dismutase assay kit, and glutathione assay kit (Cayman chemicals, Ann Arbor, MI, USA) as per manufacturer's protocol.

\subsection{Estimation of HSPs in Serum}

Serum levels of four heat shock proteins (HSP20, HSP40, HSP70, and HSP90) in infested and control animals were measured by ELISA-based methodology on biotin double antibody sandwich technology using commercial kits (Porcine HSP20, HSP40, SHP70 and HSP90 ELISA kit, Arsh Biotech Pvt. Ltd., Life Technologies, Delhi, India). Briefly, serum samples were added to the wells pre-coated with the respective HSP monoclonal antibodies. This was followed by the addition of respective anti-HSP antibodies labeled with biotin-streptavidin-HRP complex. Washing was done to remove the unbound proteins. This was followed by the addition of substrates and measurement of absorbance at $450 \mathrm{~nm}$ using a microplate reader (SpectraMax Plus, Molecular Devices, San Jose, CA, USA).

\subsection{Measurement of Cortisol in Serum}

Cortisol level in serum was measured by ELISA, based on biotin double antibody sandwich technology using a commercial kit (Porcine Cortisol ELISA kit, Arsh Biotech Pvt. Ltd., Life Technologies, Delhi, India) as per the protocol of the manufacturer. Briefly, serum samples were added to cortisol monoclonal antibodies pre-coated wells. This was followed by the addition of anti-cortisol antibodies labeled with biotin-streptavidin-HRP complex. Washing was done to remove the unbound proteins. This was followed by the addition of substrates and measurement of absorbance at $450 \mathrm{~nm}$ using a microplate reader (SpectraMax Plus, Molecular Devices, San Jose, CA, USA). The reference value of cortisol is presented in Table S2.

\subsection{Lipid Profile Analysis}

Serum levels of total cholesterol (TC), high-density lipoprotein cholesterol (HDLc), low-density lipoprotein cholesterol (LDLc), and triglycerides (TG) were evaluated. Levels of TC, HDLc, and TG were determined by enzymatic methods using commercially available kits (Jeev Diagnostics Pvt. Ltd., Chennai, India; Pathozyme Diagnostics, Kholapur, India; and Spinreact, S.A., Spain respectively). The concentration of LDL was deduced by the following formula: LDL $=\mathrm{TC}-\mathrm{HDL}-(\mathrm{TG} \div 5)$ [43]. Moreover, we calculated cardiac risk factor (CRF) and atherogenic index (AI) using the following formulas: $\mathrm{CRF}=\mathrm{TC} / \mathrm{HDL}[44]$ and $\mathrm{AI}=(\mathrm{TC}-\mathrm{HDL}) / \mathrm{HDL}$ [45]. The reference values of the parameters are presented in Table S2.

\subsection{Estimation of Serum Immune Parameters}

The concentrations of total IgG, IgA, and IgM in serum were determined using quantitative ELISA kits (Arsh Biotech Pvt. Ltd., Delhi, India) according to the manufacturer's instructions.

Serum levels of cytokines (IL-2, IL-4, IL6, IL-8, IL-12, IL-1 $\beta$, IFN- $\gamma$ ) in the serum of $S$. scabiei-infested and control animals were measured by sandwich ELISA methodology using commercial kits from Life Technologies, New Delhi, India. 


\subsection{Estimation of Apoptotic Markers}

Serum concentrations of three apoptotic markers (Caspase-3, Caspase-7, and Casepase-8) were estimated by Nori ${ }^{\circledR}$ porcine ELISA kits (Life Technologies Pvt. Ltd., Delhi, India) according to the manufacturer's manual.

\subsection{Histopathology}

Skin scrapings from infested animals were collected and fixed in formalin solution (10\%) at room temperature and a routine process was adopted for histopathology. In brief, samples were passed through ascending grades of alcohol (70-100\%) for dehydration. The dehydrated samples were then cleared in benzene, transferred to melted paraffin $\left(60^{\circ} \mathrm{C}\right)$ for impregnation, and paraffin blocks were finally prepared in metal molds. Sections were prepared by using microtome (Leica, Wetzlar, Germany; Catalogue No. RM2235) at 5 $\mathrm{M}$ Slides were prepared as per standard protocol and were stained with hematoxylin and eosin.

\subsection{Statistical Analysis}

Data were presented as mean \pm standard deviation and were normally distributed. Differences among control and infested groups were calculated by $t$-test using GraphPad Prism software (San Diego, CA, USA) (http://www.graphpad.com). The mean values with a significance of $p<0.05$ were considered to be statistically significant.

\section{Results}

\subsection{Clinical Signs of the Infested Animals}

Clinical examination showed intense pruritus associated with hyperkeratosis and crusts in the skin. Skin of the animals was thickened and wrinkled in appearance which was a characteristic feature of crusted scabies/Norwegian scabies. Alopecia in the affected area was observed (Figure 1a).

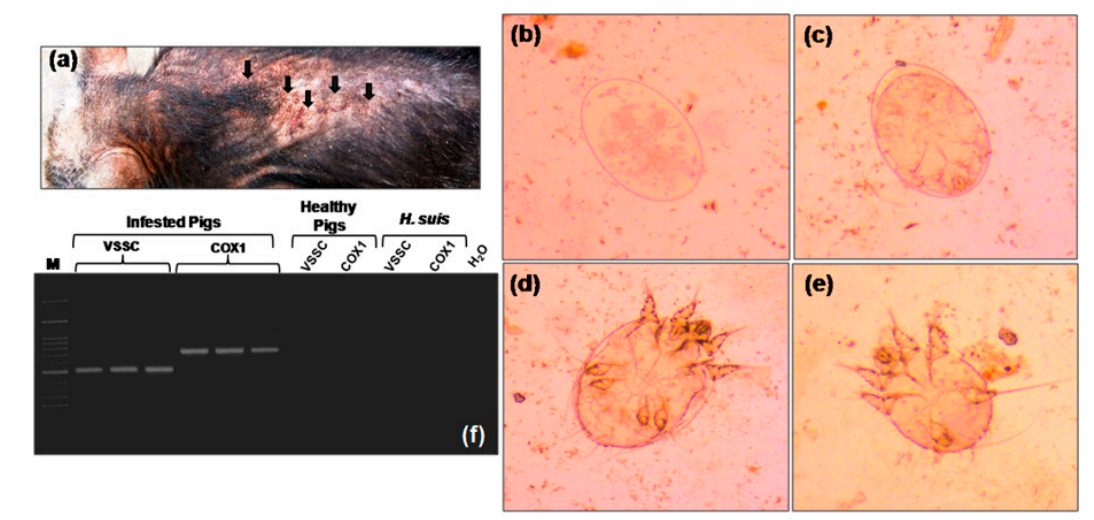

Figure 1. Sarcoptes scabiei infestation in Nicobari pig. (a) An infested animal with thickened and wrinkled skin and hair loss (black arrows), (b) mite egg (400× magnification), (c) mite egg containing larvae (400× magnification), (d) mite nymph (400× magnification), (e) larval stage of mite (400× magnification), (f) amplification of cytochrome C oxidase subunit 1 (COX1) and voltage sensitive sodium channel (VSSC) gene segments. Infested animals were positive for both of the gene fragments whereas control animals were negative. Primer specificity was verified using the lice (Haematopinus suis) DNA as negative control.

\subsection{Microscopic Examination}

On the basis of clinical symptoms, skin scrapings from infested animals were examined under microscope for the presence of mites. Microscopic examination confirmed the presence of eggs, eggs with six-legged larvae, and nymphal stage of $S$. scabiei (Figure 1b-e). The nymphal stages had 
short legs. The third and fourth pair of legs never projected beyond the body. Morphologically the mites were indistinguishable from Sarcoptes [12].

\subsection{Molecular Identification and Characterization of S. scabiei}

For molecular confirmation, one mitochondrial gene (COX1) and one nuclear gene (VSSC) were amplified using Sarcoptes specific primers and amplicons of both the genes were detected in infested pigs whereas in control pig, no amplicons were observed (Figure 1f). Specificity of the PCR was verified by using pig lice (Haematopinus suis) DNA as a negative control for both the genes (Figure 1f).

For differential diagnosis and molecular characterization, we generated partial sequence information of COX1 (2 samples) and VSSC (one sample) and the sequences were deposited in GenBank and obtained accession number MN986997-MN986998 for COX1 and MN986999 for VSSC. The sequences of COX1 and VSSC were $686 \mathrm{bp}$ and $498 \mathrm{bp}$ in length respectively. For phylogenetic analysis, we retrieved representative S. scabiei COX1 and VSSC sequences from different hosts distributed in different geographical regions. COX1 based phylogenetic tree (Figure 2a) indicated three distinct clades; two for human isolates (Clade A and B) and one for animal isolates (Clade C). In Clade A, two clearly defined clusters were detected; one includes human isolates from Hong Kong, South Korea, China and the other includes human isolates from France and Australia. Clade B contains human isolates from Panama. On the contrary, no host or region-specific clusters were observed in animal clade (Clade C). From the phylogenetic tree, it was evident that the Andaman isolates were phylogenetically close to pig isolate of Israel. A median-joining network was constructed to understand the evolutionary relationship of S. scabiei isolates. Two human-specific clades and one animal-specific clade were detected (Figure 2b).

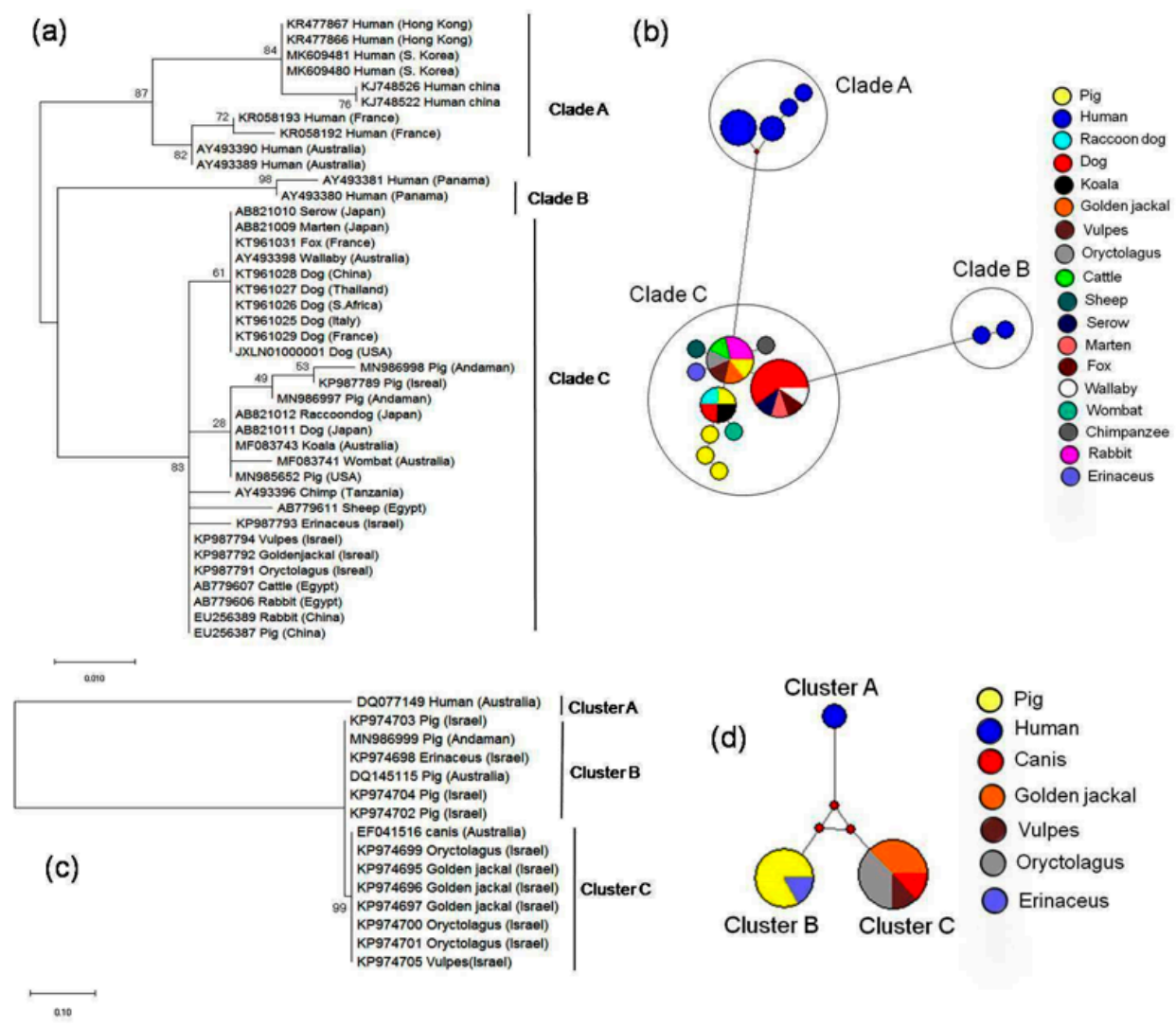

Figure 2. Evolutionary relationship of different isolates of S. scabiei. (a) COX1 based phylogenetic tree, (b) COX1 based network profile, (c) VSSC based phylogenetic tree, (d) VSSC-based network profile. Phylogenetic tree was constructed based on maximum likelihood method using Tamura-Nei model [41] implemented in MEGAX following 1000 bootstrap replications. Network was drawn in Network 10 with default settings [42]. 
Phylogenetic tree based on VSSC sequences showed three host-specific distinct clusters, one for human isolate (Cluster A) and the other two for animal isolates (Figure 2c). Within animal isolates, pig and erinaceus isolates formed one cluster (Cluster B) whereas oryctolagus, golden jackal, vulpes, and canis isolates formed another cluster (Cluster C). Pig isolates of Andaman belonged to Cluster B with pig isolates from Israel, Australia, and erinaceus isolate from Israel. The VSSC based network tree is presented in Figure 2d and three clearly defined clusters were depicted.

\subsection{Serum Biochemical Parameters in Crusted Scabies}

A significant decrease in plasma, total protein, albumin, and glucose, and significant increase in globulin, ASL, ALT, CK, LDL, and ALP in infested group as compared to those of control group was observed (Figure 3). Moreover, the ration of albumin and globulin (A:G) in infested group $(0.6359 \pm 0.048)$ was decreased than that of control group $(1.121 \pm 0.066)$.

(a)

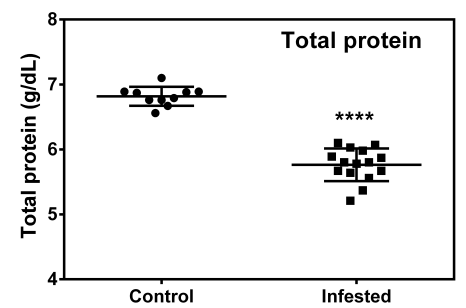

(d)

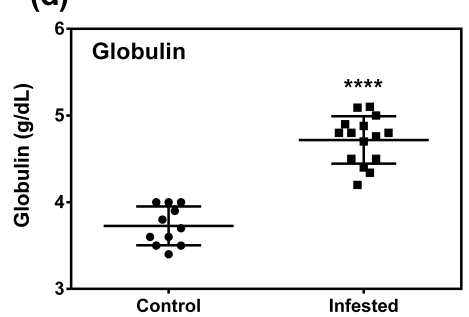

(g)

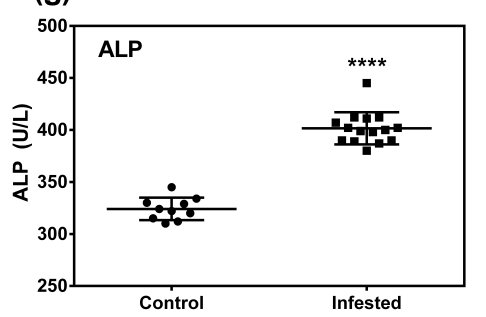

(b)

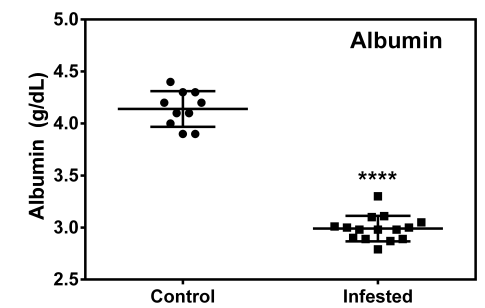

(e)

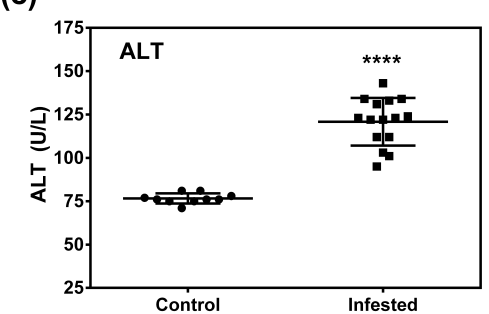

(h)

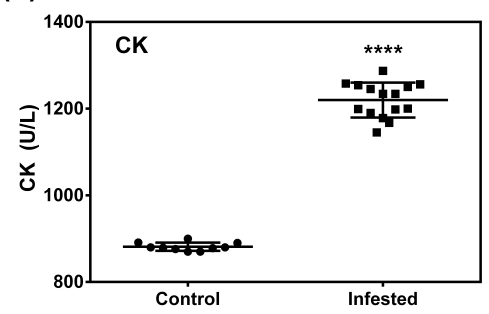

(c)

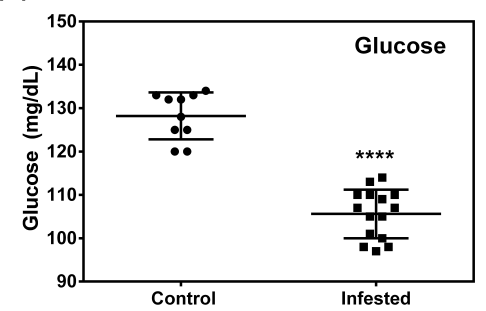

(f)

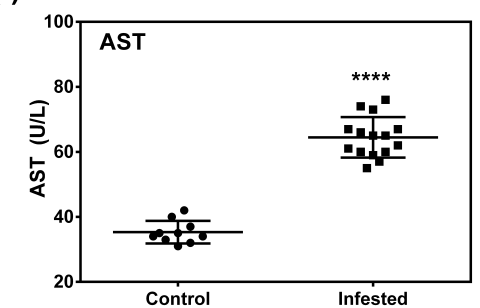

(i)

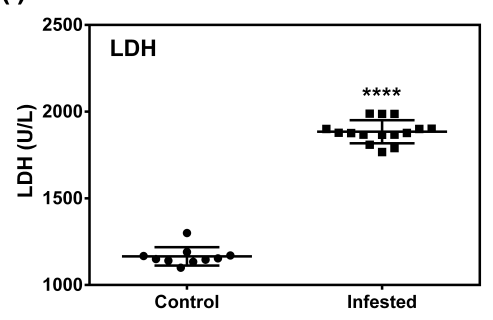

Figure 3. Effect of crusted scabieson serum biochemical parameters in a porcine model. (a) Serum total protein, (b) serum albumin, (c) serum glucose, (d) serum globulin, (e) alanine aminotransferase (ALT), (f) aspartate aminotransferase (AST), (g) alkaline phosphatase (ALP), (h) creatine kinase (CK), (i) lactate dehydrogenase $(\mathrm{LDH})$. Data in scatter plot are shown as mean \pm SD. $t$-test was performed to find out significant difference between the two groups. ${ }^{* * *}$ denotes $p \leq 0.0001$.

\subsection{Crusted Scabies Leads to Dyslipidemia in Pigs}

The results of the lipid profile analysis are presented in Figure 4. In the infested group, an atherogenic dyslipidemic profile indicated by elevated levels of total cholesterol, low-density lipoprotein cholesterol (LDL-c) and triglycerides (TG), and a decreased level of high-density lipoprotein cholesterol (HDLc) as compared to control group was observed. This was further supported by higher $\mathrm{CRF}$ and $\mathrm{AI}$ values in infested animals than those of control animals. 
(a)

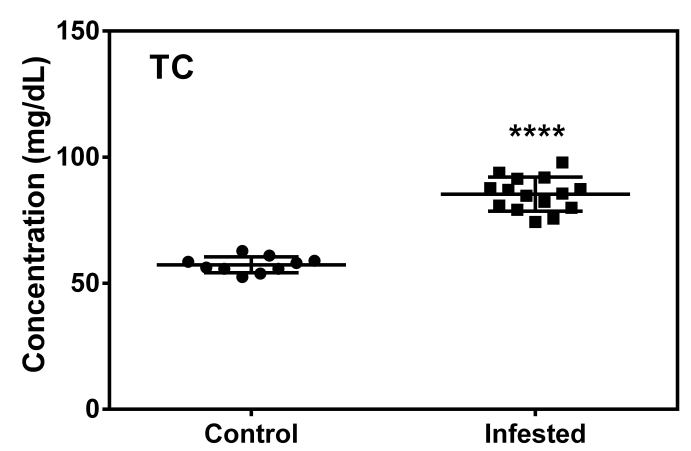

(c)

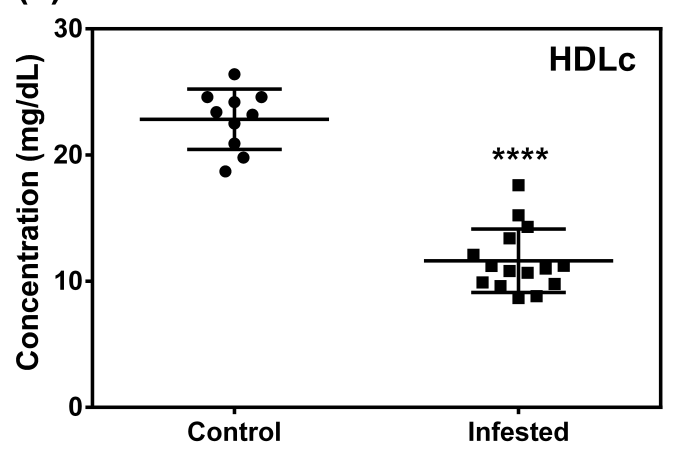

(e)

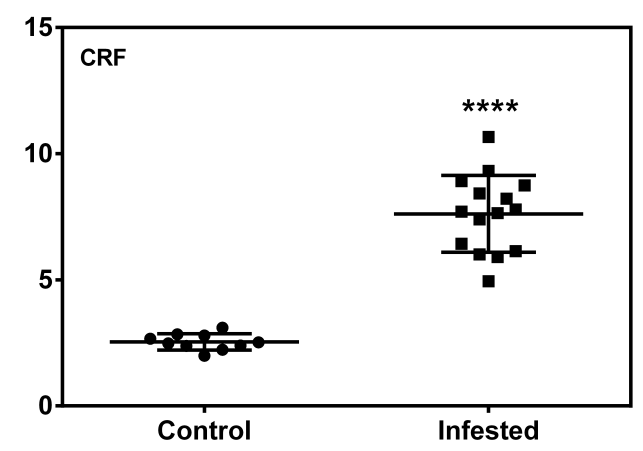

(b)

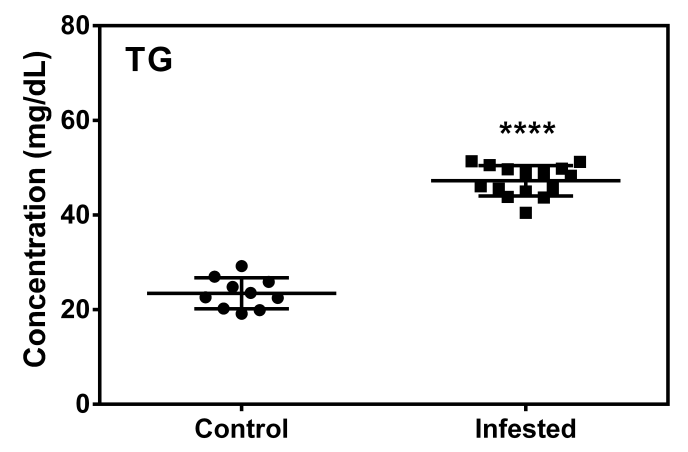

(d)

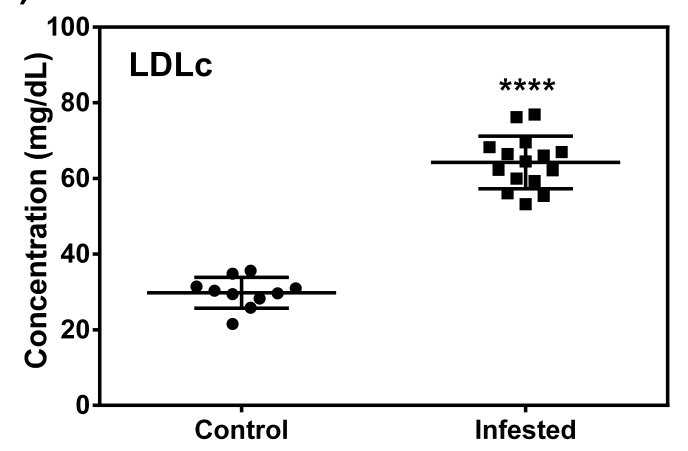

(f)

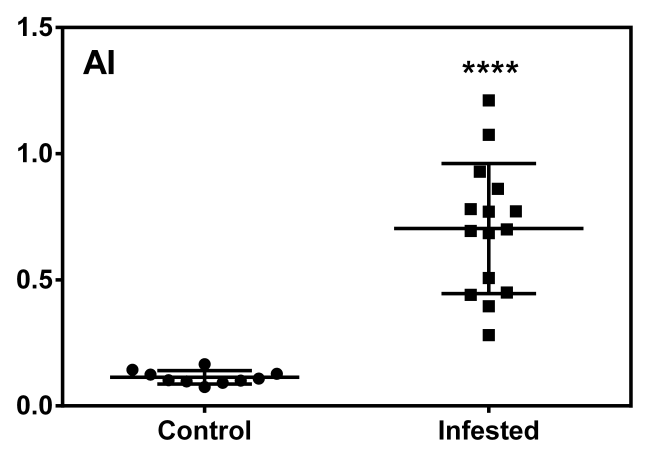

Figure 4. Effect of crusted scabies on serum lipid profile in a porcine model. (a) Total cholesterol (TC) concentration, (b) triglycerides (TG) concentration, (c) high-density lipoprotein cholesterol (HDLc) concentration, (d) low-density lipoprotein cholesterol (LDLc) concentration, (e) cardiac risk factor (CRF), (f) atherogenic index (AI). Data in scatter plot are shown as mean \pm SD. $t$-test was performed to find out significant difference between the two groups. ${ }^{* * * *}$ denotes $p \leq 0.0001$.

\subsection{Crusted Scabies Induces Oxidative Stress}

To investigate the effect of $S$. scabiei infestation on oxidant/antioxidant balance in serum, the markers of oxidative stress such as total antioxidant activity (T-AOC), total nitric oxide (TNO) concentration, levels of lipid peroxides, and malonyldialdehyde (MDA) as well as the levels of antioxidant enzymes; superoxide dismutase (SOD), glutathione-S-transferase (GSH) and catalase were determined and compared to control animals (Figure 5). The infested group showed significantly higher serum total nitric oxide (TNO) concentration than the control group. Total antioxidant activity (T-AOC) in the infested group was significantly lower than that of control group. Activity of catalase, SOD, and concentration of GSH in infested animals decreased significantly as compared to those of control animals. On the other hand, MDA concentration in the infested group was found significantly higher than its corresponding value in the control group (Figure 5). 
(a)

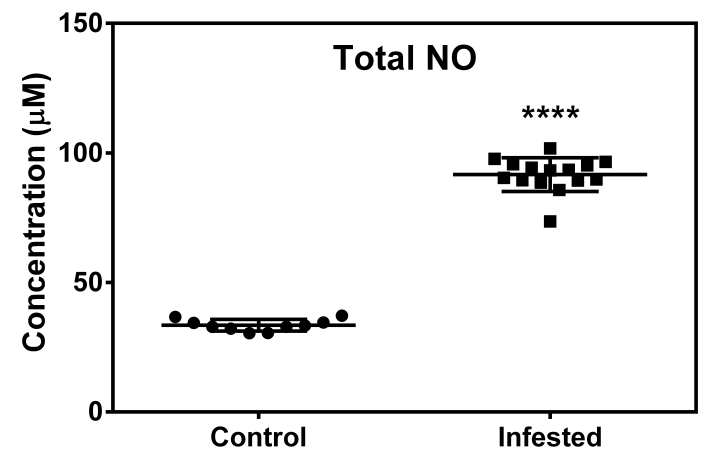

(c)

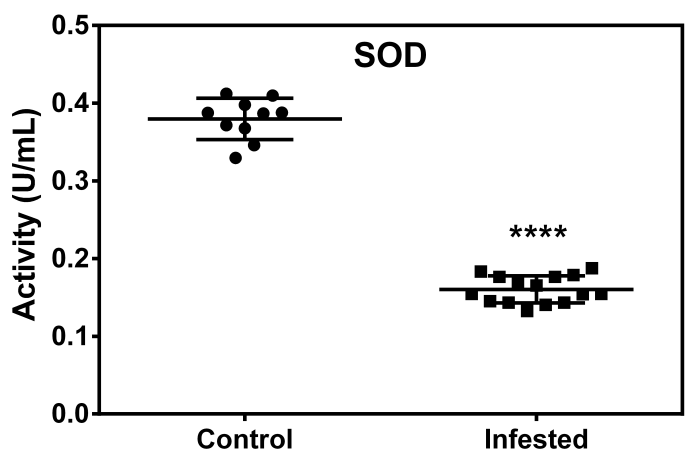

(e)

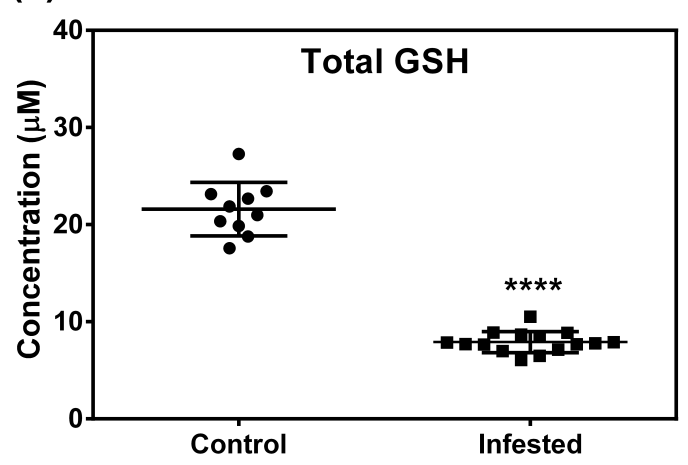

(b)

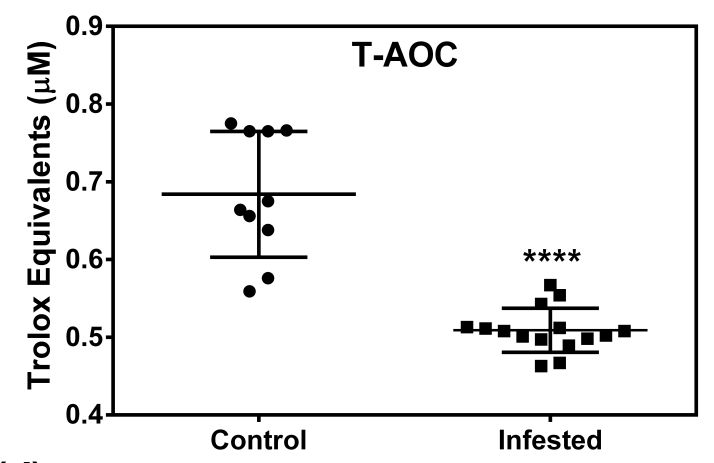

(d)

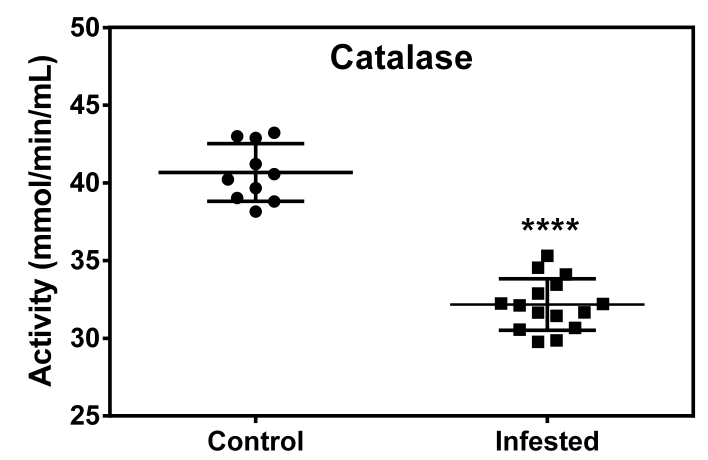

(f)

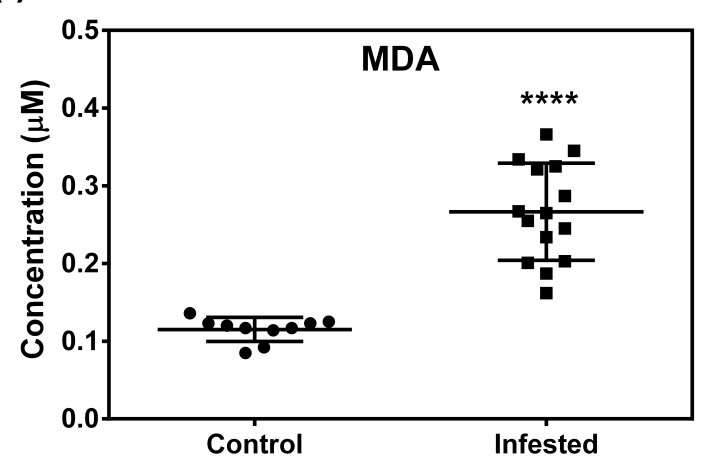

Figure 5. Effect of crusted scabies on antioxidant profiles and oxidative stress indicator in a porcine model. (a) Total nitric oxide (NO) concentration, (b) total antioxidant capacity (T-AOC), (c) superoxide dismutase (SOD) activity, (d) catalase activity, (e) glutathione-S-transferase (GSH) concentration, (f) malonyldialdehyde (MDA) concentration. Data in scatter plot are shown as mean \pm SD. $t$-test was performed to find out significant difference between the two groups. ${ }^{* * *}$ denotes $p \leq 0.0001$.

\subsection{Crusted Scabies Is Associated with Stress}

To investigate whether S. scabiei infestation leads to stress in host animals, level of stress biomarkers such as serum cortisol concentration and serum levels of four heat shock proteins (HSP20, HSP40, HSP70, and HSP90) in control and infested animals were analyzed. Serum cortisol concentration in infested group was found significantly higher than that of control group (Figure 6). 


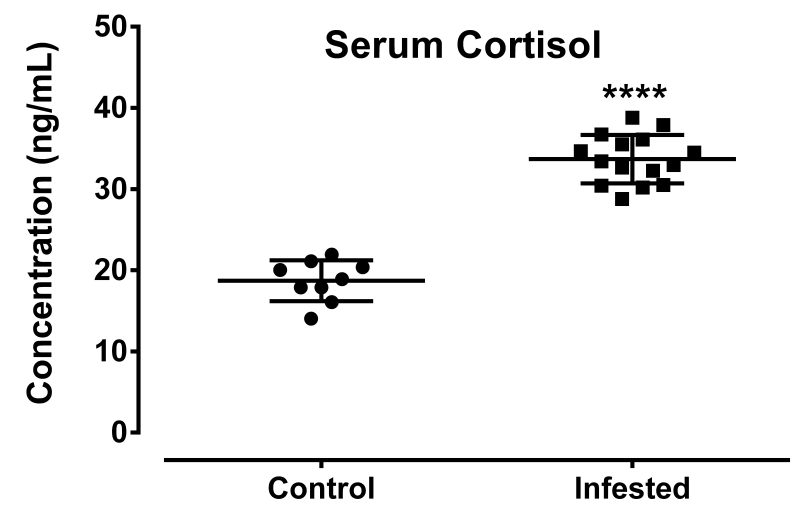

Figure 6. Effect of crusted scabieson serum cortisol concentration in a porcine model. Data in scatter plot are shown as mean $\pm \mathrm{SD}$. $t$-test was performed to find out significant difference between the two groups. ${ }^{* * * *}$ denotes $p \leq 0.0001$.

HSP20, HSP70, and HSP90 were up-regulated in infested animals compared with the control animals. On the other hand, no significant change in HSP40 level between control and infested animals was detected (Figure 7).

(a)

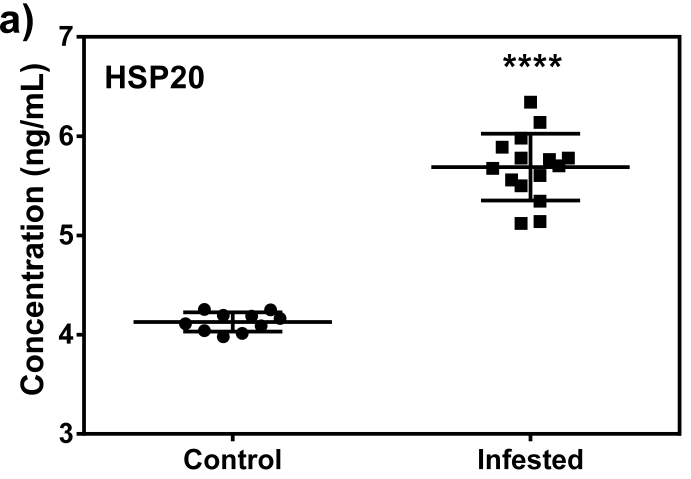

(c)

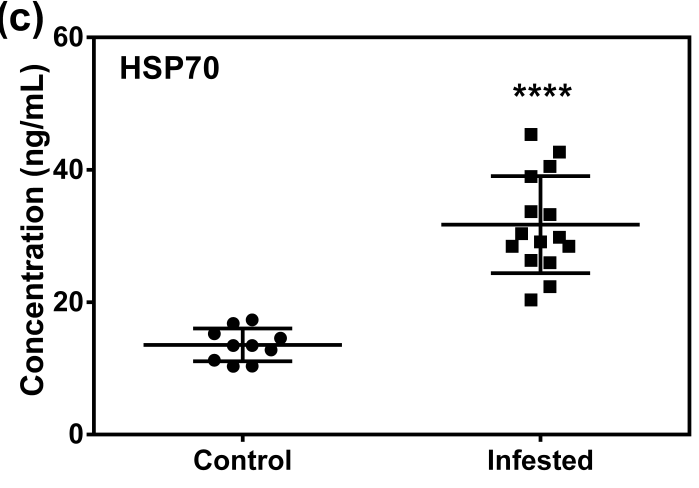

(b)

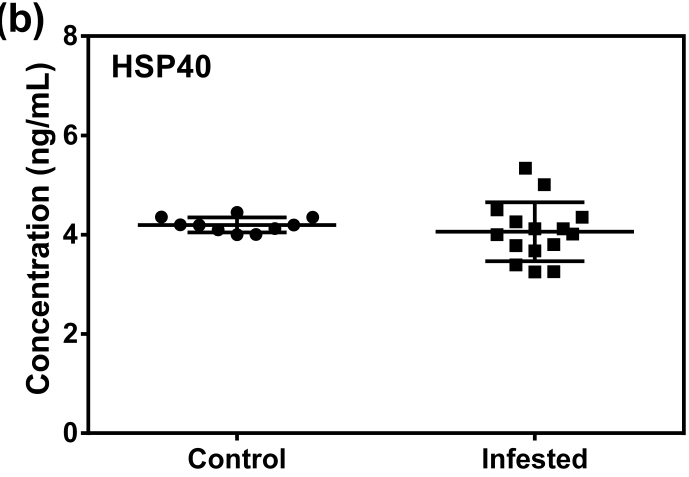

(d)

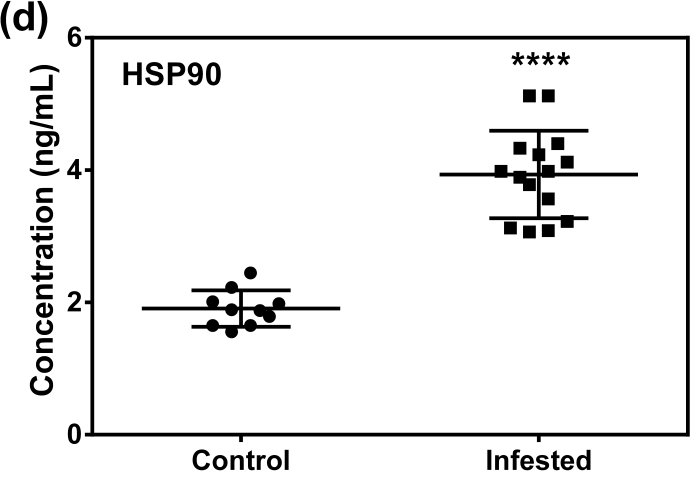

Figure 7. Effect of crusted scabies on serum heat shock proteins (HSPs) concentration in a porcine model. (a) HSP20, (b) HSP40, (c) HSP70, and (d) HSP90.Data in scatter plot are shown as mean \pm SD. $t$-test was performed to find out significant difference between the two groups. ${ }^{* * *}$ denotes $p \leq 0.0001$.

\subsection{Crusted Scabies Up-Regulates Serum Levels of Apoptotic Markers}

Serum concentrations of all three apoptotic markers (Caspase 3, 7, and 8) in infested and control animals were recorded. Up-regulation of all three apoptotic markers was detected in infested group as compared to control group (Figure 8). 
(a)

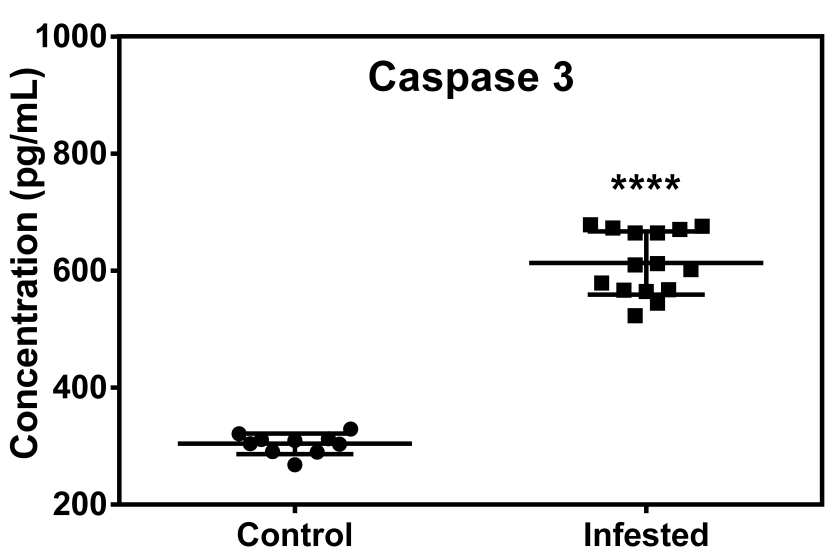

(b)

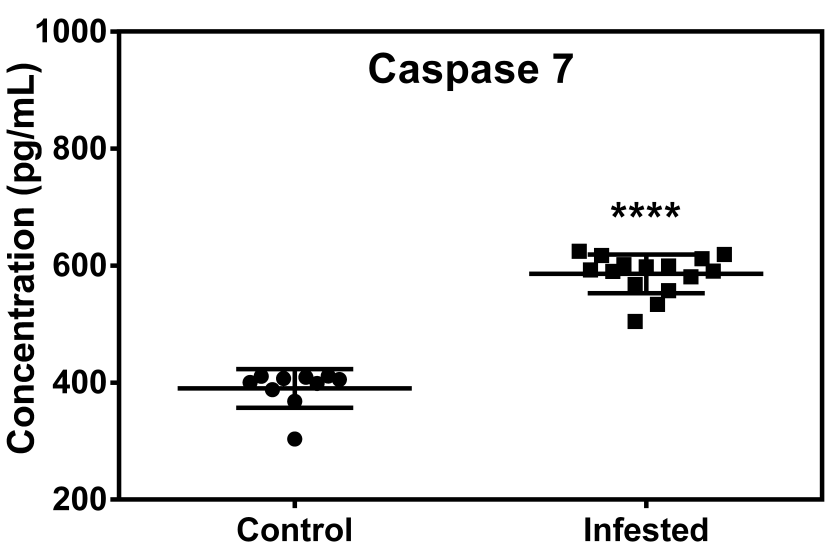

(c)

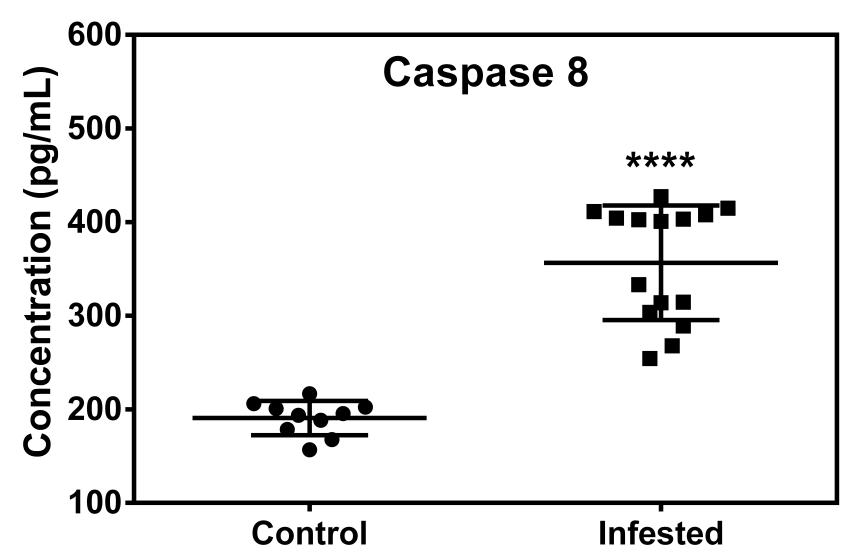

Figure 8. Effect of crusted scabieson serum levels of apoptotic markers in a porcine model. (a) Caspase 3, (b) caspase 7, (c) caspase 8. Data in scatter plot are shown as mean \pm SD. $t$-test was performed to find out significant difference between the two groups. ${ }^{* * * *}$ denotes $p \leq 0.0001$.

\subsection{Crusted Scabies Alters Immune Response}

Effect of S. scabiei infestation on the concentration of immunoglobulins and the level of cytokines were evaluated. Significantly higher concentrations of serum IgA, IgG, and IgM were detected in the infested group as compared to those of the control group (Figure 9a-c). Up-regulation of pro-inflammatory cytokines (IL-2, IL-6, IL-12, IL-1 $\beta$, and IFN- $\gamma$ ) and anti-inflammatory cytokine IL-4 were detected in the infested group than the control group (Figure $9 \mathrm{~d}-\mathrm{j}$ ). On the other hand, no significant difference in IL-8 concentration between the two groups was detected (Figure 9g). 
(a)

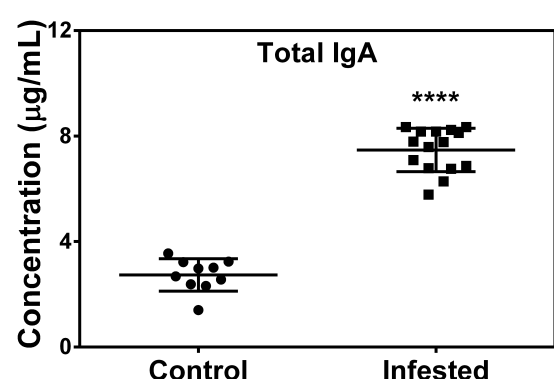

(c)

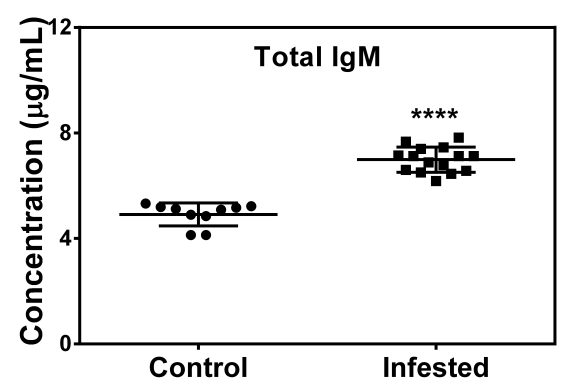

(e)

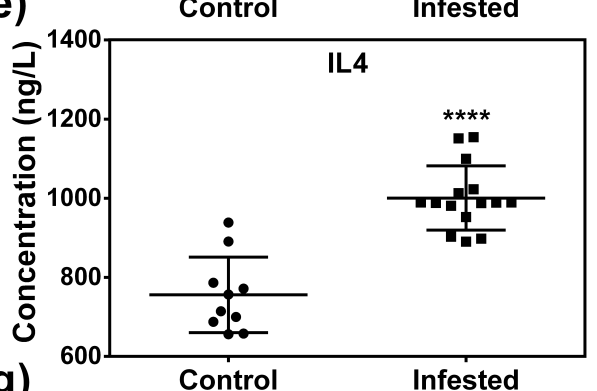

(g)

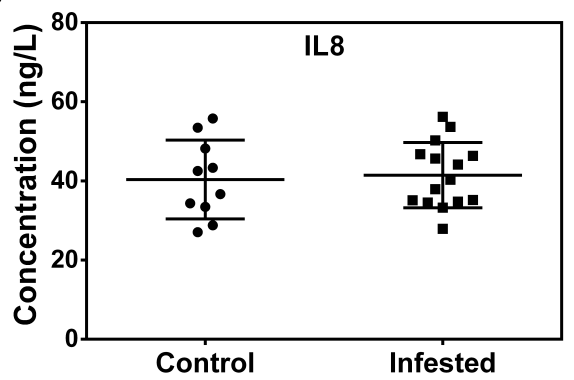

(i)

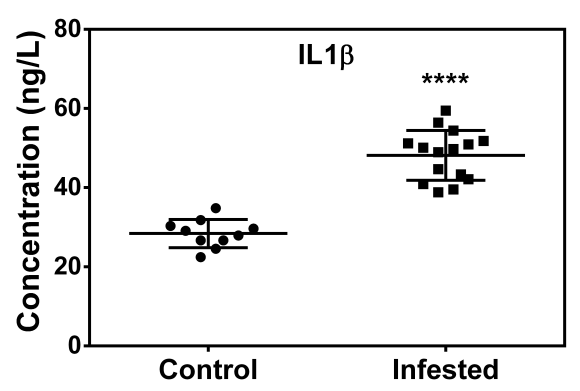

(b)

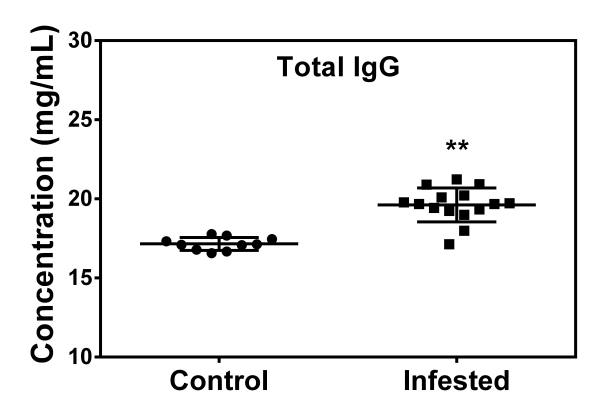

(d)

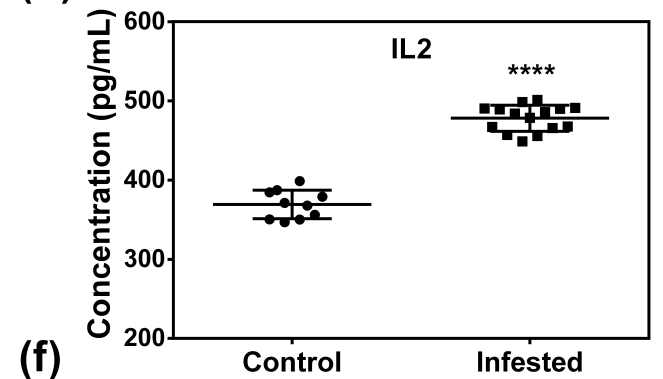

(f)

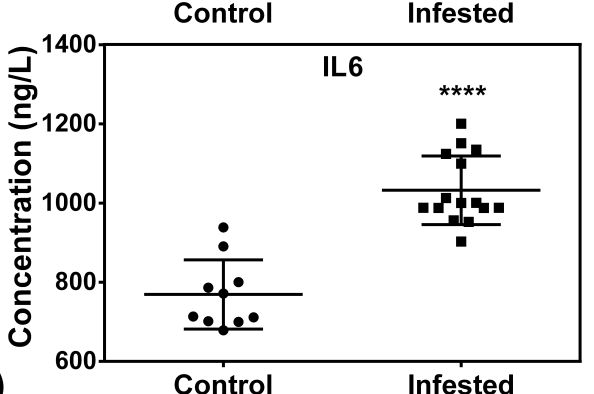

(h)

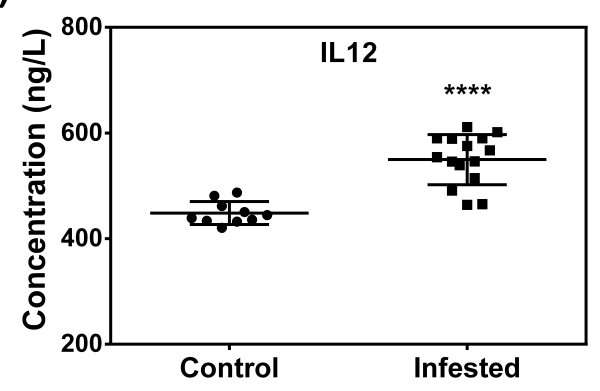

(j)

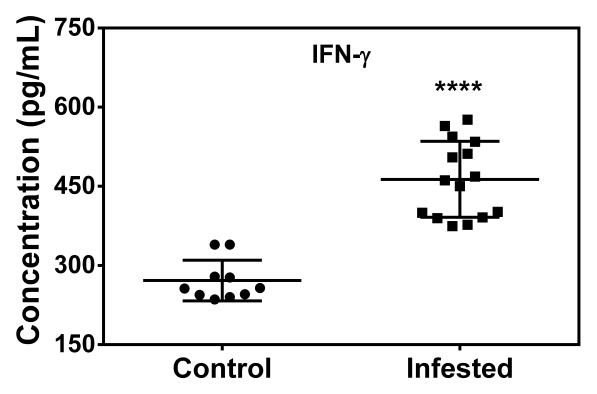

Figure 9. Effect of crusted scabieson total serum immunoglobulins and cytokine response in a porcine model. (a) Total IgA, (b) total IgG, (c) total IgM, (d) IL-2, (e) IL-4, (f) IL-6, (g) IL-8, (h) IL-12, (i) IL-1 $\beta$, and (j) IFN- $\gamma$. Data in scatter plot are shown as mean \pm SD. $t$-test was performed to find out significant difference between the two groups. ${ }^{* *}$ denotes $p \leq 0.01,{ }^{* * *}$ denotes $p \leq 0.0001$.

\subsection{Histopathology}

Parakeratotic hyperkeratosis characterized by thickening of the stratum corneum and the presence of nuclei was observed. Mite with its exoskeleton and remnants were detected in the tunnel of stratum 
corneum of the epidermis and appeared as a cleft in the upper epidermis. Epidermis exhibited acanthosis and spongiosis associated with dense eosinophilic dermal infiltrate. Superficial perivascular or diffuse infiltrate of lymphocytes and histiocytes, accompanied by neutrophils and eosinophils were evident in the dermis. There was psoriasiform hyperplasia characterized by epidermal projections into the dermis for interdigitaion with dermal papillae. Excessive production of squames suggested crust formation (Figure 10).

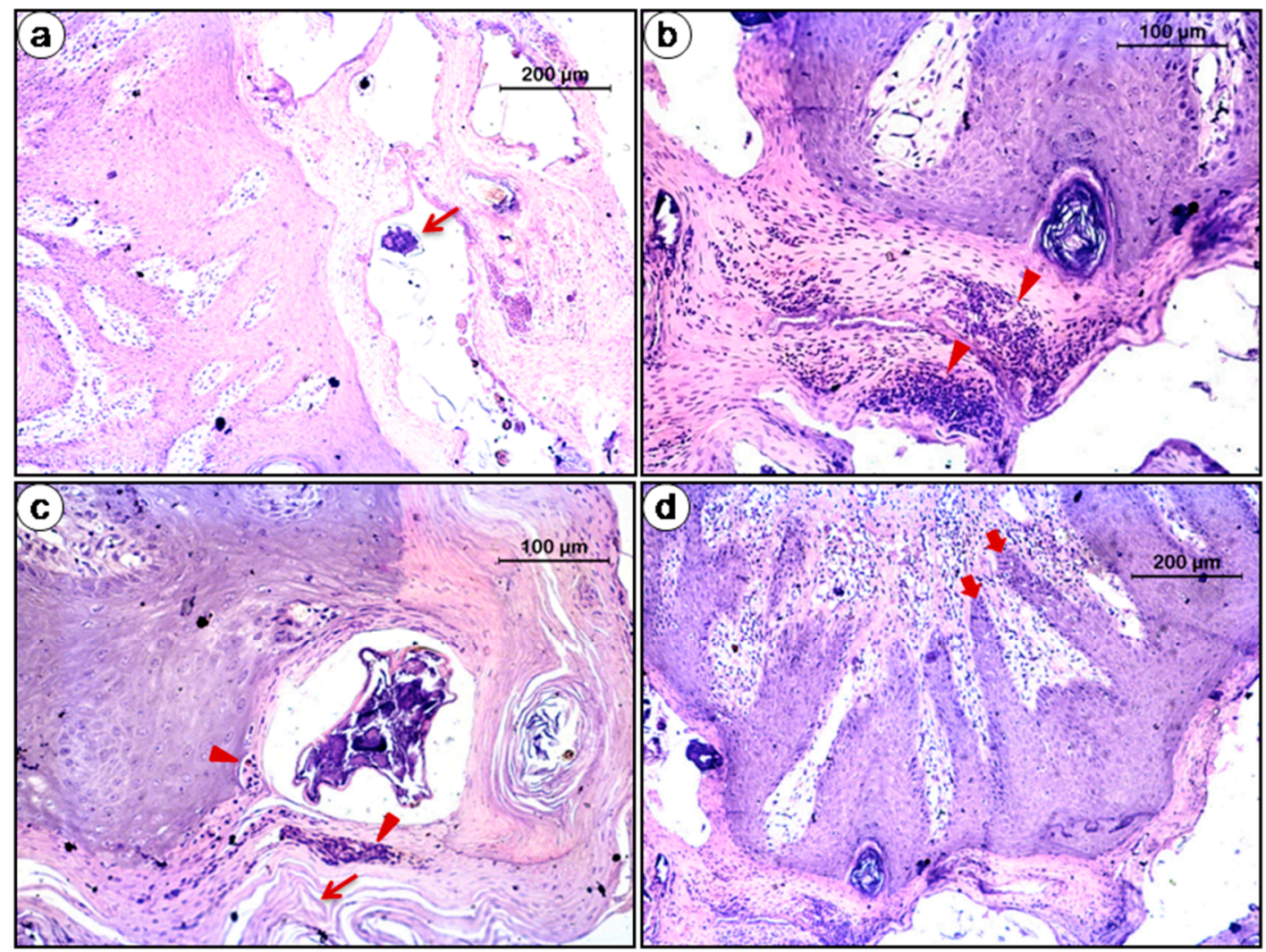

Figure 10. Histopathology of infested skin (a) Mite (arrow) with its exoskeleton and remnants prevailed in the tunnel of stratum cornium of epidermis (original magnification $100 \times$, scale bar: $200 \mu \mathrm{m}),(\mathbf{b}, \mathbf{c})$ Parakeratotic hyperkeratosis characterized by upsurge in the thickness of the stratum corneum and excessive production of squames (arrow) followed by infiltration (arrow head) into epidermis suggested crust formation. There was infiltration of cells especially eosinophils (arrow head) into epidermis and dermal vascular area causing dermatitis (original magnification 200×, scale bar: $100 \mu \mathrm{m}$ ), (d) Psoriasiform hyperplasia: Note the epidermal projections (block arrow) into the dermis for interdigitaion with dermal papillae (original magnification 100×, scale bar: $200 \mu \mathrm{m}$ ).

\section{Discussion}

Scabies is considered a disease of resource-poor communities of underdeveloped and developing countries and a neglected tropical disease [46]. Wide host range and presence of different varieties necessitate differential identification for epidemiological study and for designing eradication strategy. S. scabiei infestation in multiple hosts including humans, companion animals, farm animals, lab animals, and wild animals throughout the globe points toward pathogen dispersal and spillover [47,48]. Bidirectional interactions among human, animals, pathogen, and environment might be the underlying reason behind its multi-host adaptation [49]. As morphological and serological tests are not much successful at variety level identification, molecular markers have emerged as alternative differential diagnostic tools. Mitochondrial cytochrome C oxidase subunit I gene (COX1) is a well-established universal marker for species identification due to its high variability [50,51] and is being used extensively for DNA bar-coding of medically important parasites [52]. Erster et al. [34] used nuclear marker 
VSSC for genetic characterization of S. scabiei from multiple hosts in Israel. In the present study, we used COX1 and VSSC markers for molecular characterization of the S. scabiei isolated from pig host. COX1 based phylogenetic tree (Figure 2a) indicated that isolates under animal clade (Clade C) were phylogenetically closer to Clade B (human isolates from Panama) than Clade A (human isolates from Hong Kong, South Korea, China, France, and Australia). In general, human isolates of S. scabiei are heterogeneous in nature, and proximity of Clade B and Clade C may be due to low gene flow between mites of those groups [53]. COX1 and VSSC based phylogenetic study could not distinguish host or geographical specific isolates belonging to animal origin. Absence of host-specific cluster among animal isolates argues against the hypothesis of delineating $S$. scabiei as per host origin and provides support to the hypothesis that $S$. scabiei from different hosts and different geographical location arose from a single speciation event $[16,54,55]$. Evolution of different varieties in different hosts might be due to mitochondrial capture or selective sweep phenomenon which is considered as the driving force behind uniparental inheritance [56]. This hypothesis has been proposed as the adaptation of Sarcoptes in different marsupials in Australia [48]. Moreover, parasites with low independent dispersal capacities face strong population bottlenecks; under such situations they lower their genetic diversity to maintain their adaptive potential $[57,58]$. This might explain the low genetic diversity in S. scabiei among animal isolates.

S. scabiei is a contagious disease with a broad host range of more than 100 species and its effects across species are generally conserved [59]. Therefore, it is reasonable to assume that understanding the changes in one host may have significance in other hosts [60]. In recent years, pigs have gained popularity as a biomedical model in translational research due to its anatomical and physiological similarity with humans $[61,62]$. Close resemblance between human and pig in clinical manifestation and disease progression of $S$. scabiei $[63,64]$ underscore the importance of porcine model in understanding host-parasite interactions of scabies/mange. The present study showed marked changes in serum biochemical parameters, lipid profiles, stress parameters, oxidant/antioxidant balance, and immune parameters following crusted scabies in a porcine model.

Increased ALT, AST, ALP, LDH, CK, and decreased albumin and glucose levels in infested animals indicate organ damage, especially compromised liver function [65]. Oxidative stress has been associated with cell necrosis and apoptosis through activation of several cell signaling pathways such as JNK, mitogen-activated protein kinase (MAPK) leading to cellular and organ damage [66,67]. It is a well-established fact that oxidative stress causes liver injury [68] as the liver is a major target organ of ROS [69]. Moreover, free radicals, especially ROS catalyze the oxidation of LDL to generate oxidized LDL and oxidized LDL also promotes cellular apoptosis in different organs [67,70]. In the present study, crusted scabies induced oxidative stress in pigs which might have detrimental effects on organs including the liver. Oxidative stress-induced organ damage might explain elevated levels of AST, ALT, and alkaline phosphatase. Alteration in the biochemical parameters was also reported in sarcoptic mange affected goats and dogs $[37,38,71]$. As the liver is the major organ for albumin synthesis and glucose generation through gluconeogenesis and glucogenolysis [72], impaired liver function may attribute low levels of glucose and albumin in infested animals. In addition, high ROS has been reported to impair insulin signaling $[73,74]$ causing an increase in insulin secretion; which might be another reason for low glucose concentration in infested animals. On the contrary, up-regulation in globulin production in infested animals might be due to the production of antibodies against S. scabiei antigens [38]. Low glucose and albumin and high globulin were also reported in Sarcoptes-infested goats [37] and dogs [38].

Abnormal blood lipid metabolites including elevated TC, LDLc, and TG were detected in infested animals than control animals. Imbalance in lipid metabolites is considered to be a predisposing cause of atherosclerosis and cardiovascular disorders [75]. In the present study, atherogenic dyslipidemia associated with high CRF and AI values in infested animals is an indicator of their susceptibility towards cardiovascular diseases. Imbalance in lipid metabolism is associated with many dermatological disorders especially chronic inflammatory skin diseases such as psoriasis, litchen planus, granuloma 
annulare, and histiocytosis [76]. Chronic inflammation in animals with crusted scabies may explain the abnormal lipid profiles. Moreover, oxidative stress which was also observed in the present study induced production of TNF-Alpha by Kupffer cells, which might induce inflammation [68]. Increased levels of pro-inflammatory cytokines following infestation might be the underlying cause behind dyslipidemia [76]. Increased serum levels of pro-inflammatory cytokines such as IL-2, IL-6, IL-12, IL-1 $\beta$, and IFN- $\gamma$ in infested animals were detected in the present study. Pro-inflammatory cytokines such as IL-6, IFN- $\gamma$ inhibit the activity of lipoprotein lipase (LPL) [77] which hampers the clearance of VLDL and LDL cholesterol $[78,79]$ leading to their increased concentration in blood. Moreover, crusted scabies induced oxidative stress in animals, and under oxidative stress, ROS induced activation of atherogenic genes via NF-kappa B [67] may further explain the atherogenic dyslipidemia in infested animals. In addition, alopecia due to infestation results in disruption of pelt-environment interface which in turn hampers thermoregulation as excessive heat loss to the environment occurs through the skin. This creates a negative energy balance to the host [60]. Mobilization of fat from fat stores to meet the energy deficiency may induce imbalance in lipid profile. An imbalance in fatty acid composition in adipose tissue with up-regulated omega- 6 acids and down-regulated omega- 3 acids in S. scabiei infested wombat host was reported [60]. The results of the study indicate that crusted scabies may shift lipid profile towards atherogenic dyslipidemia with high susceptibility towards cardiovascular disorder.

We determined the serum concentration of cortisol which is considered a biomarker of stress. The study found a significant increase in serum cortisol concentration in infested animals than control animals which indicated that infestation triggered stress response. Hypothalamic-pituitary-adrenal (HPA) axis, an important hormonal regulator of stress, is thought to be involved in the production of cortisol hormone [80]. In stressful conditions, activation of HPA axis followed by elevated plasma cortisol level is an adaptive response of the host [81]. HSPs are constitutively produced in normal physiological conditions whereas stress of any kind including environmental stress, viral infection, glucose deprivation, exposure of toxins, and oxidative stress induce over-expression of HSPs or cell-stress proteins [82]. HSPs are a classic example of proteins with 'moonlighting functions' [83] as they are involved in a number of physiological functions. Besides acting as chaperone and protein folding, involvement of HSPs in immune function such as antigen processing and presentation, expression of innate receptors and stimulation of innate immunity is well documented [84]. Moreover, HSPs, especially HSP70 and 27 play vital roles in stress-induced DNA repair by modulating DNA-repair enzymes, thus maintaining genome integrity [84]. Stress up-regulates the intracellular production of HSPs and they are released into the circulation following a non-classical secretion pathway [85]. In the present study, crusted scabies induced cellular and oxidative stress which in turn might have stimulated over-expression of HSPs. Thus, HSP orchestrated activation of heat shock response is an adaptation mechanism under stress [86]. Oxidative stress shifts the intracellular environment towards the oxidative state which in turn disturbs the protein native conformation and proteins lose their folded structure [86]. HSPs act as sensors to cellular redox changes both in prokaryotes and in eukaryotes; then give signals for activation of the heat stress response [86]. HSP70 and HSP90 act as the primary sensors of protein misfolding. Moreover, HSP27 has been reported to act as an antioxidant by preventing oxidation of glutathione under oxidative stress [87]. HSP70 and HSP90 act as anti-apoptotic proteins; they exert their role by binding to apoptosis protease activity factor 1 (Apaf-1) blocking downstream cascades of apoptosis pathway $[88,89]$. In the present study, the infested animals under oxidative stress might have induced cellular apoptosis. This is supported by the up-regulation of serum levels of apoptotic markers in infested animals. The up-regulation of HSPs in infested animals might be an adaptation mechanism to prevent cellular apoptosis.

Oxidative stress has been reported to be involved in the pathogenesis of several diseases including parasitic infections [90]. Cellular metabolism produces reactive oxygen species (ROS) and reactive nitrogen species (RNS) [91]. At a low to moderate level, they are involved in several physiological functions including cell signaling as well as immune functions [92]. On the contrary, at a high level, 
they cause damage to molecules including lipids, proteins, lipoproteins, and nucleic acids starting a chain reaction of free radical formation leading to a condition known as oxidative stress $[93,94]$. Therefore, tight regulation in production of ROS and RNS and delicate balance between beneficial and detrimental effects is vital for cellular homeostasis. Under oxidative stress, the antioxidant defense system elicits several antioxidant enzymes to fight against free radicals and maintain homeostasis. Superoxide dismutase, catalase, and glutathione peroxidase act as first-line defense antioxidants to suppress or prevent the formation of reactive species in cells [95]. SOD catalyzed the conversion of $\mathrm{O}_{2}{ }^{-}$ into $\mathrm{H}_{2} \mathrm{O}_{2}$ which is further reduced to $\mathrm{H}_{2} \mathrm{O}$ and $\mathrm{O}_{2}$ by either catalase or glutathione peroxidase [96]. In the present study, it was observed that crusted scabies caused an increase in the production of serum total NO in pigs. Though we did not measure ROS, oxidative stress induction in infested animals was evident from the reduction of total antioxidant capacity, activity of catalase, SOD, and concentration of GSH as well as an increase in MDA concentration as compared to control animals. The down-regulation of T-AOC and antioxidant enzymes indicate that they have been over-consumed to tackle oxidative stress [97]. The results of our study are in agreement with the report of Beighet al. [98], in which decreased catalase and GSH in dogs suffering from dermatophytosis was reported. A decrease in antioxidant enzyme activities was also reported in buffaloes infested by sarcoptic mange [99] and in sheep, which was suffering from psoroptic mange [100]. Increased MDA concentration in infested animals indicated oxidative injury. Cell membranes with a rich store of polyunsaturated fatty acids are excellent targets for free radical attacks [101] and oxidation of lipid molecules induce production of MDA [102]. So, MDA, the end product of lipid peroxidation, is considered as a hallmark of oxidative damage [103]. In the present study, increased MDA concentration in infested animals might be associated with cellular damage. An increase in skin MDA in S. scabiei infested dogs were reported by Nwufoh et al. [104].

S. scabiei infestation is associated with modulation of various parameters of host immune responses; humoral, adaptive, and inflammatory immune responses [31,33]. $\operatorname{IgA}, \operatorname{IgG}$, and $\operatorname{IgM}$ are the major immunoglobulins associated with humoral immunity. IgM is produced at the early stage of antibody response against a foreign antigen. IgG, being the most abundant antibody in blood and extracellular fluid, is involved in systemic immune response. IgA is generally associated with mucosal immunity and primarily found in secretions [105]. In the present study, up-regulation of total IgA, IgG, and IgM in infested pigs than the control group was observed. Elevated levels of immuniglobulins in infested animals indicated that mite had elicited antibody-mediated immune response against mite antigens although it was not possible to know whether or not the antibody response was S. scabiei specific. Up-regulation of total IgG might be a consequence of secondary bacterial infection which is very common in scabies infestation. Increased IgG in S. scabiei infested rabbits, dogs $[21,106]$, and human [107] was reported. Elevated levels of circulatory IgA were reported in human crusted scabies [107].

We further assessed the systemic inflammatory response of the animals by determining serum levels of pro-inflammatory cytokines including IL-1 $\beta$, IL-2, IL-6, IL-12, and IFN- $\gamma$ and anti-inflammatory cytokine IL-4. Cytokines play key roles in the host immune and inflammatory responses as well as in the maintenance of tissue integrity [108]. The present study recorded dysregulation of cytokine balance which might be due to modulation of immunity by S. scabiei released antigens. Th1 and Th2 are the two major subpopulations of $\mathrm{T}$ helper cells and parasitic infections are associated with either Th1 or Th2 polarized immune response [109]. IL-2, TNF- $\beta$, and IFN- $\gamma$ are Th1 cells specific cytokines whereas Th2 cells release IL-4, IL-5, IL-10, and IL-13 as signature cytokines [110]. Naïve helper T cells (Th0) can be differentiated to either Th1 or Th2 based on distinct activation pathways; cytokines such as IFN- $\gamma$ andIL-12 activates Th 0 to Th1 cells, otherwise, IL-10 and IL- 4 are crucial stimulatory cytokines for Th2 cell polarization [111]. Intricate balance among different cytokines is crucial for homeostasis of mammalian species and imbalance may pose threat to health [112]. In the present study, S. scabiei infestation was associated with up-regulation of IL-2, IFN- $\gamma$, IL-1 $\beta$, and IL-4 indicating both Th1 and Th 2 response. The most probable cause of the mixed Th1/Th2 response might be dysregulation 
of cytokine balance due to modulation of immunity by S. scabiei released antigens or changes of cytokine levels after a chronic infection. Th1 immune response is generally associated with protection in most infectious diseases whereas Th2 immune response elicits high titers of antibody production and cell-mediated inflammation [113]. Moreover, allergic inflammatory diseases are dominated by Th2 immune response [6]. Induction of mixed Th1/Th2 immune response in the current study indicates that the immune response to mange infestation is complex and local immune response analysis is necessary for a better understanding of the disease. Th2 response had been described as a predominant immune response in crusted scabies and other allergic inflammatory disorders [6]. Bioactive compounds in arthropod saliva trigger different immune response to host. Low molecular weight salivary components cannot act as antigen but can bind to skin proteins as haptens and stimulate Th1 response. Some salivary antigens may cause basophil hypersensitivity (Th1 response) by binding to epidermal langerhans cells. Salivary antigens also may trigger Th2 response in association with IgE production and type I hypersensitivity [107].

The histopathological findings in the study mimic the classical narrative of sarcoptic mange in mammalian species [3]. Antigenic materials including excretion and secretions of mites trigger hypersensitivity reactions in the skin [114] which might be the reason behind eosinophilia observed in the infested animals. Our observations are consistent with those in vulpes [115], racoon dog [116], wombats [117] and Iberian ibex [118].

\section{Conclusions}

This communication is the first report on genetic characterization of S. scabiei from India. Mitochondrial (COX1) or nuclear (VSSC) based markers could not distinguish S. scabiei at a variety level especially for animal isolates which suggests that delineating varieties based on host origin is not warranted. The study contributes to the rich pool of knowledge on the consequences of crusted scabies on host physiology. We could establish a new connection showing that mange infestation results in an atherogenic dyslipidemia in the host.

Supplementary Materials: The following are available online at http://www.mdpi.com/2076-2615/10/12/2312/s1, Table S1: COX1 and VSSC sequences used in the study, Table S2: Reference values of different biochemical parameters in pigs.

Author Contributions: Conceptualization, A.K.D. and S.S.; methodology, A.K.D., S.S., P.P., S.M., S.K.R., G.S. and K.M.; software, A.K.D. and S.B.; validation, D.M. and A.K.; formal analysis, A.K.D. and A.K.B.; investigation, A.K.T., D.B., G.S., and A.K.D.; resources, A.K.D., D.B. and A.K.; data curation, A.K.D.; writing-original draft preparation, A.K.D.; writing-review and editing, D.B.; visualization, D.B.; supervision, S.B.; project administration, A.K.D.; funding acquisition, A.K.D. All authors have read and agreed to the published version of the manuscript.

Funding: This research was funded by a Grant from All India Coordinated Research Project on Pig (AICRP on Pig), Indian Council of Agricultural Research, New Delhi, India with Grant number AICRP-Pig/ICAR-CIARI.

Acknowledgments: The authors acknowledge the Director, ICAR-Central Island Agricultural Research Institute (CIARI), Port Blair, Andaman and Nicobar Islands, India for providing all the necessary facilities to carry out the present study.

Conflicts of Interest: The authors declare no conflict of interest. The funders had no role in the design of the study; in the collection, analyses, or interpretation of data; in the writing of the manuscript, or in the decision to publish the results.

\section{References}

1. Heukelbach, J.; Wilcke, T.; Winter, B.; Feldmeier, H. Epidemiology and morbidity of scabies and pediculosis capitis in resource-poor communities in Brazil. Br. J. Dermatol. 2005, 153, 150-156. [CrossRef] [PubMed]

2. Alasaad, S.; Rossi, L.; Heukelbach, J.; Pérez, J.M.; Hamarsheh, O.; Otiende, M.; Zhu, X.Q. The neglected navigating web of the incomprehensibly emerging and re-emerging Sarcoptes mite. Infect. Genet. Evol. 2013, 17, 253-259. [CrossRef] [PubMed] 
3. Bornstein, S.; Morner, T.; Samuel, W.M. Sarcoptesscabiei and sarcoptic mange. In Parasitic Diseases of Wild Mammals, 2nd ed.; Samuel, W.M., Pybus, M.J., Kocan, A.A., Eds.; Manson Publishing: London, UK, 2001; pp. 107-119.

4. Walton, S.F.; Currie, B.J. Problems in diagnosing scabies, a global disease in human and animal populations. Clin. Microbiol. Rev. 2007, 20, 268-279. [CrossRef] [PubMed]

5. Dagleish, M.P.; Ali, Q.; Powell, R.K.; Butz, D.; Woodford, M.H. Fatal Sarcoptesscabiei infection of blue sheep (Pseudoisnayaur) in Pakistan. J. Wildl. Dis. 2007, 43, 512-517. [CrossRef] [PubMed]

6. Bhat, S.A.; Mounsey, K.E.; Liu, X.; Walton, S.F. Host immune responses to the itch mite, Sarcoptesscabiei, in humans. Parasites Vectors 2017, 10, 385. [CrossRef] [PubMed]

7. Hengge, U.R.; Currie, B.J.; Jäger, G.; Lupi, O.; Schwartz, R.A. Scabies: A ubiquitous neglected skin disease. Lancet Infect. Dis. 2006, 6, 769-779. [CrossRef]

8. Terry, B.C.; Kanjah, F.; Sahr, F.; Kortequee, S.; Dukulay, I.; Gbakima, A.A. Sarcoptesscabiei infestation among children in a displacement camp in Sierra Leone. Public Health 2001, 115, 208-211. [CrossRef]

9. Carapetis, J.R.; Connors, C.; Yarmirr, D.; Krause, V.; Currie, B.J. Success of a scabies control program in an Australian aboriginal community. Pediatr. Infect. Dis. J. 1997, 16, 494-499. [CrossRef]

10. Andrews, R.M.; McCarthy, J.; Carapetis, J.R.; Currie, B.J. Skin disorders, including pyoderma, scabies, and tinea infections. Pediatr. Clin. N. Am. 2009, 56, 1421-1440. [CrossRef]

11. Currie, B.J.; McCarthy, J.S. Permethrin and ivermectin for scabies. N. Engl. J. Med. 2010, 362, 717-725. [CrossRef]

12. Soulsby, E.J.L. Helminths, Arthropods and Protozoa of Domesticated Animals, 7th ed.; Bailliere Tindall: London, UK, 1982.

13. Walton, S.F.; Dougall, A.; Pizzutto, S.; Holt, D.; Taplin, D.; Arlian, L.G.; Morgan, M.; Currie, B.J.; Kemp, D.J. Genetic epidemiology of Sarcoptesscabiei (Acari: Sarcoptidae) in northern Australia. Int. J. Parasitol. 2004, 34, 839-849. [CrossRef] [PubMed]

14. Daszak, P.; Cunningham, A.A.; Hyatt, A.D. Emerging infectious diseases of wildlife-Threats to biodiversity and human health. Science 2000, 287, 443-449. [CrossRef] [PubMed]

15. Alasaad, S.; Oleaga, Á.; Casais, R.; Rossi, L.; Min, A.M.; Soriguer, R.C.; Gortázar, C. Temporal stability in the genetic structure of Sarcoptesscabiei under the host-taxon law: Empirical evidences from wildlife-derived Sarcoptes mite in Asturias, Spain. Parasites Vectors 2011, 4, 151. [CrossRef] [PubMed]

16. Berrilli, F.; D'Amelio, S.; Rossi, L. Ribosomal and mitochondrial DNA sequence variation in Sarcoptes mites from different hosts and geographical regions. Parasitol. Res. 2002, 88, 772-777. [CrossRef] [PubMed]

17. Menzano, A.; Rambozzi, L.; Rossi, L. Outbreak of scabies in human beings, acquired from chamois (Rupicaprarupicapra). Vet. Rec. 2004, 155, 568. [CrossRef]

18. Wallgren, P.; Bornstein, S. The spread of porcine sarcoptic mange during the fattening period revealed by development of antibodies to Sarcoptesscabiei. Vet. Parasitol. 1997, 73, 315-324. [CrossRef]

19. Fain, A. Epidemiological problems of scabies. Int. J. Dermatol. 1978, 17, 20-30. [CrossRef]

20. Alasaad, S.; Soglia, D.; Spalenza, V.; Maione, S.; Soriguer, R.C.; Pérez, J.M.; Rasero, R.; Degiorgis, M.P.; Nimmervoll, H.; Zhu, X.Q.; et al. Is ITS-2 rDNA suitable marker for genetic characterization of Sarcoptes mites from different wild animals in different geographic areas? Vet. Parasitol. 2009, 159, 181-185. [CrossRef]

21. Arlian, L.G.; Morgan, M.S.; Arends, J.J. Immunologic cross-reactivity among various strains of Sarcoptesscabiei. J. Parasitol. 1996, 82, 66-72. [CrossRef]

22. Garcia, R.; Piche, C.; Davies, P.; Gross, S. Prevalence of sarcoptic mange mites and dermatitis in slaughter pigs in North America and Western Europe. In Proceedings of the 13th Conference of the International Pig Veterinary Society, Bangkok, Thailand, 26-30 June 1994; p. 250. Available online: https://agris.fao.org/agrissearch/search.do? recordID=TH2000001208 (accessed on 5 October 2020).

23. Jensen, J.C.; Nielsen, L.H.; Arnason, T.; Cracknell, V. Elimination of mange mites Sarcoptesscabiei var. suis from two naturally infested Danish sow herds using a single injection regime with doramectin. Acta Vet. Scand. 2002, 43, 75-84. [CrossRef]

24. Davies, P.R. Sarcoptic mange and production performance of swine: A review of the literature and studies of associations between mite infestation, growth rate and measures of mange severity in growing pigs. Vet. Parasitol. 1995, 60, 249-264. [CrossRef]

25. Arends, J.J.; Stanislaw, C.M.; Gerdon, D. Effects of sarcoptic mange on lactating swine and growing pigs. J. Anim. Sci. 1990, 68, 1495-1499. [CrossRef] [PubMed] 
26. Henken, A.M.; Verstegen, M.W.A.; Van Der Hel, W.; Boon, J.H.A. Pilot study of parasite worry and restlessness caused by sarcoptic mange in swine. In Proceedings of the 10th Conference of the International Pig Veterinary Society, Rio de Janerio, Brazil, 14-17 August 1988.

27. Grahofer, A.; Bannoehr, J.; Nathues, H.; Roosje, P. Sarcoptes infestation in two miniature pigs with zoonotic transmission-A case report. BMC Vet. Res. 2018, 14, 91. [CrossRef] [PubMed]

28. Sokolova, T.V.; Lange, A.B. Parazito-khoziainnaiaspetsifichnost' chesotochnogozudnia Sarcoptesscabiei (Acariformes: Sarcoptidae) chelovekaizhivotnykh (obzorliteratury) [The parasite-host specificity of the itch mite Sarcoptesscabiei (Acariformes: Sarcoptidae) in man and animals (a review of the literature)]. Parazitologiia 1992, 26, 97-104.

29. Chakrabarti, A. Pig handler's itch. Int. J. Dermatol. 1990, 29, 205-206. [CrossRef]

30. Laha, R. Sarcoptic mange infestation in pigs: An overview. J. Parasit. Dis. 2015, 39, 596-603. [CrossRef]

31. Morgan, M.S.; Arlian, L.G.; Markey, M.P. Sarcoptesscabiei mites modulate gene expression in human skin equivalents. PLOS ONE 2013, 8, e71143. [CrossRef]

32. Mullins, J.S.; Arlian, L.G.; Morgan, M.S. Extracts of Sarcoptesscabiei De Geer down-modulate secretion of IL-8 by skin keratinocytes and fibroblasts and of GM-CSF by fibroblasts in the presence of proinflammatory cytokines. J. Med. Entomol. 2009, 46, 845-851. [CrossRef]

33. Cote, N.M.; Jaworski, D.C.; Wasala, N.B.; Morgan, M.S.; Arlian, L.G. Identification and expression of macrophage migration inhibitory factor in Sarcoptesscabiei. Exp. Parasitol. 2013, 135, 175-181. [CrossRef]

34. Erster, O.; Roth, A.; Pozzi, P.S.; Bouznach, A.; Shkap, V. First detection of Sarcoptesscabiei from domesticated pig (Sus scrofa) and genetic characterization of $S$. scabiei from pet, farm and wild hosts in Israel. Exp. Appl. Acarol. 2015, 66, 605-612. [CrossRef]

35. Morgan, M.S.; Arlian, L.G. Response of human skin equivalents to Sarcoptesscabiei. J. Med. Entomol. 2010, 47, 877-883. [CrossRef] [PubMed]

36. Lalli, P.N.; Morgan, M.S.; Arlian, L.G. Skewed Th1/Th2 immune response to Sarcoptesscabiei. J. Parasitol. 2004, 90, 711-714. [CrossRef] [PubMed]

37. De, U.K.; Dey, S. Evaluation of organ function and oxidant/antioxidant status in goats with sarcoptic mange. Trop. Anim. Health Prod. 2010, 42, 1663-1668. [CrossRef] [PubMed]

38. Beigh, S.A.; Soodan, J.S.; Bhat, A.M. Sarcoptic mange in dogs: Its effect on liver, oxidative stress, trace minerals and vitamins. Vet. Parasitol. 2016, 227, 30-34. [CrossRef]

39. Thompson, J.D.; Higgins, D.G.; Gibson, T.J. CLUSTAL W: Improving the sensitivity of progressive multiple sequence alignment through sequence weighting, position-specific gap penalties and weight matrix choice. Nucleic Acids Res. 1994, 22, 4673-4680. [CrossRef] [PubMed]

40. Kumar, S.; Stecher, G.; Li, M.; Knyaz, C.; Tamura, K. MEGA X: Molecular Evolutionary Genetics Analysis across Computing Platforms. Mol. Biol. Evol. 2018, 35, 1547-1549. [CrossRef]

41. Tamura, K.; Nei, M. Estimation of the number of nucleotide substitutions in the control region of mitochondrial DNA in humans and chimpanzees. Mol. Biol. Evol. 1993, 10, 512-526. [CrossRef]

42. Bandelt, H.J.; Forster, P.; Röhl, A. Median-joining networks for inferring intraspecific phylogenies. Mol. Biol. Evol. 1999, 16, 37-48. [CrossRef]

43. Yu, I.T.; Ju, C.C.; Lin, J.; Wu, H.L.; Yen, H.T. Effects of probiotics and selenium combination on the immune and blood cholesterol concentration of pigs. J. Anim. Feed Sci. 2004, 13, 625-634. [CrossRef]

44. Marbut, M.M.; Majeed, B.M.; Rahim, S.M.; Yuusif, M.Y. Estimation of malondialdehyde as oxidative factor and glutathione as early detectors of hypertensive pregnant women. Tikrit Med. J. 2009, 15, 63-69.

45. Campbell, J.M.; Crenshaw, J.D.; Polo, J. The biological stress of early weaned piglets. J. Anim. Sci. Biotechnol. 2013, 4, 19. [CrossRef] [PubMed]

46. Steer, A. Scabies Joins the List of WHO Neglected Tropical Diseases. Lancet Global Health Blog. Global Health Blogs. 2014. Available online: http://globalhealth.thelancet.com/2014/07/07/scabies-joins-list-whoneglected-tropical-diseases (accessed on 3 October 2020).

47. Mounsey, K.E.; McCarthy, J.S.; Walton, S.F. Scratching the itch: New tools to advance understanding of scabies. Trends Parasitol. 2013, 29, 35-42. [CrossRef] [PubMed]

48. Fraser, T.A.; Shao, R.; Fountain-Jones, N.M.; Charleston, M.; Martin, A.; Whiteley, P.; Holme, R.; Carver, S.; Polkinghorne, A. Mitochondrial genome sequencing reveals potential origins of the scabies mite Sarcoptesscabiei infesting two iconic Australian marsupials. BMC Evol. Biol. 2017, 17, 233. [CrossRef] 
49. Alexander, K.A.; Carlson, C.J.; Lewis, B.L.; Getz, W.M.; Marathe, M.V.; Eubank, S.G.; Sanderson, C.E.; Blackburn, J.K. The Ecology of pathogen spillover and disease emergence at the human-wildlife-environment interface. In The Connections between Ecology and Infectious Disease; Advances in Environmental Microbiology; Hurst, C., Ed.; Springer: Cham, Switzerland, 2018; Volume 5, pp. 267-298.

50. Mandal, S.D.; Chhakchhuak, L.; Gurusubramanian, G.; Kumar, N.S. Mitochondrial markers for identification and phylogenetic studies in insects-A Review. DNA Barcodes 2014, 2, 1-9. [CrossRef]

51. Pentinsaari, M.; Salmela, H.; Mutanen, M.; Roslin, T. Molecular evolution of a widely-adopted taxonomic marker (COI) across the animal tree of life. Sci. Rep. 2016, 6, 35275. [CrossRef] [PubMed]

52. Ondrejicka, D.A.; Locke, S.A.; Morey, K.; Borisenko, A.V.; Hanner, R.H. Status and prospects of DNA barcoding in medically important parasites and vectors. Trends Parasitol. 2014, 30, 582-591. [CrossRef]

53. Andriantsoanirina, V.; Ariey, F.; Izri, A.; Bernigaud, C.; Fang, F.; Charrel, R.; Foulet, F.; Botterel, F.; Guillot, J.; Chosidow, O.; et al. Sarcoptesscabiei mites in humans are distributed into three genetically distinct clades. Clin. Microbiol. Infect. 2015, 21, 1107-1114. [CrossRef]

54. Zahler, M.; Essig, A.; Gothe, R.; Rinder, H. Molecular analyses suggest monospecificity of the genus Sarcoptes (Acari: Sarcoptidae). Int. J. Parasitol. 1999, 29, 759-766. [CrossRef]

55. Gu, X.B.; Yang, G.Y. A study on the genetic relationship of mites in the genus Sarcoptes (Acari: Sarcoptidae) in China. Int. J. Acarol. 2008, 34, 183-190. [CrossRef]

56. Christie, J.R.; Beekman, M. Selective sweeps of mitochondrial DNA can drive the evolution of uniparental inheritance. Evolution 2017, 71, 2090-2099. [CrossRef]

57. Gandon, S. Local adaptation and the geometry of host-parasite coevolution. Ecol. Lett. 2002, 5, $246-256$. [CrossRef]

58. Appelgren, A.S.C.; Saladin, V.; Richner, H.; Doligez, B.; McCoy, K.D. Gene flow and adaptive potential in a generalist ectoparasite. BMC Evol. Biol. 2018, 18, 99. [CrossRef] [PubMed]

59. Arlian, L.G.; Morgan, M.S. A review of Sarcoptesscabiei: Past, present and future. Parasites Vectors 2017, 10, 297. [CrossRef] [PubMed]

60. Martin, A.M.; Fraser, T.A.; Lesku, J.A.; Simpson, K.; Roberts, G.L.; Garvey, J.; Polkinghorne, A.; Burridge, C.P.; Carver, S. The cascading pathogenic consequences of Sarcoptesscabiei infection that manifest in host disease. R. Soc. Open Sci. 2018, 5, 180018. [CrossRef] [PubMed]

61. Prather, R.S.; Walters, E.M.; Wells, K.D. Swine in Biomedical Research 2014. Lab Anim. 2014, 44, 9. [CrossRef]

62. Monticello, T.M.; Haschek, W.M. Swine in translational research and drug development. Toxicol. Pathol. 2016, 44, 297-298. [CrossRef]

63. Mounsey, K.; Ho, M.F.; Kelly, A.; Willis, C.; Pasay, C.; Kemp, D.J.; McCarthy, J.S.; Fischer, K. A tractable experimental model for study of human and animal scabies. PLoS Negl. Trop. Dis. 2010, 4, e756. [CrossRef]

64. Rampton, M.; Walton, S.F.; Holt, D.C.; Pasay, C.; Kelly, A.; Currie, B.J.; McCarthy, J.S.; Mounsey, K.E. Antibody responses to Sarcoptesscabiei apolipoprotein in a porcine model: Relevance to immunodiagnosis of recent infection. PLoS ONE 2013, 8, e65354. [CrossRef]

65. Giannini, E.G.; Testa, R.; Savarino, V. Liver enzyme alteration: A guide for clinicians. CMAJ 2005, 172, 367-379. [CrossRef]

66. Quinn, M.T.; Parthasarathy, S.; Fong, L.G.; Steinberg, D. Oxidatively modified low density lipoproteins: A potential role in recruitment and retention of monocyte/macrophages during atherogenesis. Proc. Natl. Acad. Sci. USA 1987, 84, 2995-2998. [CrossRef]

67. Ogura, S.; Shimosawa, T. Oxidative stress and organ damages. Curr. Hypertens Rep. 2014, 16, 452. [CrossRef] [PubMed]

68. Li, S.; Tan, H.Y.; Wang, N.; Zhang, Z.; Lao, L.; Wong, C.; Feng, Y. The role of oxidative stress and antioxidants in liver diseases. Int. J. Mol. Sci. 2015, 16, 26087-26124. [CrossRef] [PubMed]

69. Sánchez-Valle, V.; Chávez-Tapia, N.C.; Uribe, M.; Méndez-Sánchez, N. Role of oxidative stress and molecular changes in liver fibrosis: A review. Curr. Med. Chem. 2012, 19, 4850-4860. [CrossRef] [PubMed]

70. Ogura, S.; Kakino, A.; Sato, Y.; Fujita, Y.; Iwamoto, S.; Otsui, K.; Yoshimoto, R.; Sawamura, T. Lox-1: The multifunctional receptor underlying cardiovascular dysfunction. Circ. J. 2009, 73, 1993-1999. [CrossRef] [PubMed]

71. Sharma, S.K.; Soodan, J.S.; Sharma, N. Haemato-biochemical alterations in canine dermatitis. Indian Vet. J. 2011, 88, 56-58. 
72. Han, H.S.; Kang, G.; Kim, J.S.; Choi, B.H.; Koo, S.H. Regulation of glucose metabolism from a liver-centric perspective. Exp. Mol. Med. 2016, 48, e218. [CrossRef] [PubMed]

73. Ogihara, T.; Asano, T.; Katagiri, H.; Sakoda, H.; Anai, M.; Shojima, N.; Ono, H.; Fujishiro, M.; Kushiyama, A.; Fukushima, Y.; et al. Oxidative stress induces insulin resistance by activating the nuclear factor-kappa B pathway and disrupting normal subcellular distribution of phosphatidylinositol 3-kinase. Diabetologia 2004, 47, 794-805. [CrossRef]

74. Fridlyand, L.E.; Philipson, L.H. Reactive species and early manifestation of insulin resistance in type 2 diabetes. Diabetes Obes. Metab. 2006, 8, 136-145. [CrossRef]

75. Misra, A.; Luthra, K.; Vikram, N.K. Dyslipidemia in Asian Indians: Determinants and significance. J. Assoc. Physicians India 2004, 52, 137-142.

76. Shenoy, C.; Shenoy, M.M.; Rao, G.K. Dyslipidemia in dermatological disorders. N. Am. J. Med. Sci. 2015, 7, 421-428. [CrossRef]

77. Hahn, B.H.; Grossman, J.; Chen, W.; McMahon, M. The pathogenesis of atherosclerosis in autoimmune rheumatic diseases: Roles of inflammation and dyslipidemia. J. Autoimmun. 2007, 28, 69-75. [CrossRef] [PubMed]

78. Kobashigawa, J.A.; Kasiske, B.L. Hyperlipidemia in solid organ transplantation. Transplantation 1997, 63, 331-338. [CrossRef] [PubMed]

79. Derfler, K.; Hayde, M.; Heinz, G.; Hirschl, M.M.; Steger, G.; Hauser, A.C.; Balcke, P.; Widhalm, K. Decreased postheparin lipolytic activity in renal transplant recipients with cyclosporin A. Kidney Int. 1991, 40, 720-727. [CrossRef] [PubMed]

80. Stephens, M.A.; Wand, G. Stress and the HPA axis: Role of glucocorticoids in alcohol dependence. Alcohol Res. 2012, 34, 468-483.

81. Li, L.A.; Yang, J.J.; Li, Y.; Lv, L.; Xie, J.J.; Du, G.M.; Jin, T.M.; Qin, S.Y.; Jiao, X.L. Effect of weaning age on cortisol release in piglets. Genet. Mol. Res. 2016, 15, 1-10. [CrossRef]

82. Pockley, A.G.; Henderson, B. Extracellular cell stress (heat shock) proteins-immune responses and disease: An overview. Philos. Trans. R. Soc. Lond. B Biol. Sci. 2018, 373, 20160522. [CrossRef]

83. Campbell, R.M.; Scanes, C.G. Endocrine peptides 'moonlighting' as immune modulators: Roles for somatostatin and GH-releasing factor. J. Endocrinol. 1995, 147, 383-396. [CrossRef]

84. Bolhassani, A.; Agi, E. Heat shock proteins in infection. Clin. Chim. Acta 2019, 498, 90-100. [CrossRef]

85. Pockley, A.G.; Bulmer, J.; Hanks, B.M.; Wright, B.H. Identification of human heat shock protein 60 (Hsp60) and anti-Hsp60 antibodies in the peripheral circulation of normal individuals. Cell Stress Chaperones 1999, 4 , 29-35. [CrossRef]

86. Kalmar, B.; Greensmith, L. Induction of heat shock proteins for protection against oxidative stress. Adv. Drug Deliv. Rev. 2009, 61, 310-318. [CrossRef]

87. Arrigo, A.P. The cellular "networking" of mammalian Hsp27 and its functions in the control of protein folding, redox state and apoptosis. Adv. Exp. Med. Biol. 2007, 594, 14-26. [CrossRef] [PubMed]

88. Yuan, J.; Murrell, G.A.; Trickett, A.; Wang, M.X. Involvement of cytochrome c release and caspase-3 activation in the oxidative stress-induced apoptosis in human tendon fibroblasts. Biochim. Biophys. Acta 2003, 1641, 35-41. [CrossRef]

89. Annunziato, L.; Amoroso, S.; Pannaccione, A.; Cataldi, M.; Pignataro, G.; D’Alessio, A.; Sirabella, R.; Secondo, A.; Sibaud, L.; Di Renzo, G.F. Apoptosis induced in neuronal cells by oxidative stress: Role played by caspases and intracellular calcium ions. Toxicol. Lett. 2003, 139, 125-133. [CrossRef]

90. Ellah, M.R.A. Involvement of free radicals in parasitic infestations. J. Appl. Anim. Res. 2013, 41, 69-76. [CrossRef]

91. Birben, E.; Sahiner, U.M.; Sackesen, C.; Erzurum, S.; Kalayci, O. Oxidative stress and antioxidant defense. World Allergy Organ. 2012, 5, 9-19. [CrossRef]

92. Valko, M.; Leibfritz, D.; Moncol, J.; Cronin, M.T.D.; Mazur, M.; Telser, J. Free radicals and antioxidants in normal physiological functions and human disease. Int. J. Biochem. Cell Biol. 2007, 39, 44-84. [CrossRef]

93. Nordberg, J.; Arnér, E.S.J. Reactive oxygen species, antioxidants, and the mammalian thioredoxin system. Free Radic. Biol. Med. 2001, 31, 1287-1312. [CrossRef]

94. Phaniendra, A.; Jestadi, D.B.; Periyasamy, L. Free Radicals: Properties, sources, targets, and their implication in various diseases. Indian J. Clin. Biochem. 2015, 30, 11-26. [CrossRef] 
95. Kurutas, E.B. The importance of antioxidants which play the role in cellular response against oxidative/nitrosative stress: Current state. Nutr. J. 2016, 15, 71. [CrossRef]

96. Griendling, K.K.; FitzGerald, G.A. Oxidative stress and cardiovascular injury: Part I: Basic mechanisms and in vivo monitoring of ROS. Circulation 2003, 108, 1912-1916. [CrossRef]

97. Beigh, S.A.; Soodan, J.S.; Nazki, S.; Khan, A.M. Oxidative stress, hematobiochemical parameters, trace elements and vitamins in dogs with zinc responsive dermatosis. VeterinarskiArhiv 2014, 84, 591-600.

98. Beigh, S.A.; Soodan, J.S.; Singh, R.; Khan, A.M.; Dar, M.A. Evaluation of trace elements, oxidant/antioxidative status, vitamin $C$ and $\beta$-carotene in dogs with dermatophytosis. Mycoses 2014, 57, 358-365. [CrossRef]

99. Dimri, U.; Sharma, M.C.; Swarup, D.; Ranjan, R.; Kataria, M. Alterations in hepatic lipid peroxides and antioxidant profile in Indian water buffaloes suffering from sarcoptic mange. Res. Vet. Sci. 2008, 85, 101105. [CrossRef] [PubMed]

100. Dimri, U.; Sharma, M.C.; Yamdagni, A.; Ranjan, R.; Zama, M.M.S. Psoroptic mange infestation increases oxidative stress and decreases antioxidant status in sheep. Vet. Parasitol. 2010, 68, 318322. [CrossRef] [PubMed]

101. Brand, A.; Bauer, N.G.; Hallott, A.; Goldbaum, O.; Ghebremeskel, K.; Reifen, R.; Richter-Landsberg, C. Membrane lipid modification by polyunsaturated fatty acids sensitizes oligodendroglial OLN-93 cells against oxidative stress and promotes up-regulation of heme oxygenase-1 (HSP32). J. Neurochem. 2010, 113, 465-476. [CrossRef] [PubMed]

102. Ardestani, A.; Yazdanparast, R. Antioxidant and free radical scavenging potential of Achillea santolina extracts. Food Chem. 2007, 104, 21-29. [CrossRef]

103. DelRio, D.; Stewart, A.J.; Pellegrini, N. A review of recent studies on malondialdehyde as toxic molecule and biological marker of oxidative stress. Nutr. Metab. Cardiovasc. Dis. 2005, 15, 316-328. [CrossRef]

104. Nwufoh, O.C.; Sadiq, N.A.; Emikpe, B.O.; Omobowale, T. Assessment of cutaneous and serum oxidative stress changes in dogs infested with Sarcoptesscabiei var. Canis. Acta Vet. Eurasia 2020, 46, 1-6. [CrossRef]

105. Luo, Q.; Cui, H.; Peng, X.; Fang, J.; Zuo, Z.; Deng, J.; Liu, J.; Deng, Y. Intestinal IgA+ cell numbers as well as IgA, IgG, and IgM contents correlate with mucosal humoral immunity of broilers during supplementation with high fluorine in the diets. Biol. Trace Elem. Res. 2013, 154, 62-72. [CrossRef]

106. Morgan, M.S.; Arlian, L.G. Serum antibody profiles of Sarcoptesscabiei infested or immunized rabbits. Folia Parasitol. 1994, 41, 223-227.

107. Roberts, L.J.; Huffam, S.E.; Walton, S.F.; Currie, B.J. Crusted scabies: Clinical and immunological findings in seventy-eight patients and a review of the literature. J. Inf. Secur. 2005, 50, 375-381. [CrossRef] [PubMed]

108. Hu, C.H.; Xiao, K.; Luan, Z.S.; Song, J. Early weaning increases intestinal permeability, alters expression of cytokine and tight junction proteins, and activates mitogen-activated protein kinases in pigs. J. Anim. Sci. 2013, 91, 1094-1101. [CrossRef]

109. Jankovic, D.; Sher, A.; Yap, G. Th1/Th2 effector choice in parasitic infection: Decision making by committee. Curr. Opin. Immunol. 2001, 13, 403-409. [CrossRef]

110. Romagnani, S. T-cell subsets (Th1 versus Th2). Ann. Allergy Asthma Immunol. 2000, 85, 9-21. [CrossRef]

111. Kaiko, G.E.; Horvat, J.C.; Beagley, K.W.; Hansbro, P.M. Immunological decision-making: How does the immune system decide to mount a helper T-cell response? Immunology 2008, 123, 326-338. [CrossRef] [PubMed]

112. Cicchese, J.M.; Evans, S.; Hult, C.; Joslyn, L.R.; Wessler, T.; Millar, J.A.; Marino, S.; Cilfone, N.A.; Mattila, J.T.; Linderman, J.J.; et al. Dynamic balance of pro- and anti-inflammatory signals controls disease and limits pathology. Immunol. Rev. 2018, 285, 147-167. [CrossRef]

113. Spellberg, B.; Edwards, J.E., Jr. Type 1/Type 2 immunity in infectious diseases. Clin. Infect. Dis. 2001, 32, 76-102. [CrossRef]

114. Pence, D.B.; Ueckermann, E. Sarcoptic mange in wildlife. Rev. Sci. Tech. Off. Int. Epizoot. 2002, 21, 385-398. [CrossRef]

115. Nimmervoll, H.; Hoby, S.; Robert, N.; Lommano, E.; Welle, M.; Ryser-Degiorgis, M.P. Pathology of sarcoptic mange in red foxes (Vulpes vulpes): Macroscopic and histologic characterization of three disease stages. J. Wildl. Dis. 2013, 49, 91-102. [CrossRef]

116. Ninomiya, H.; Ogata, M. Sarcoptic mange in free-ranging raccoon dogs (Nyctereutesprocyonoides) in Japan. Vet. Dermatol. 2005, 16, 177-182. [CrossRef] 
117. Ryser-Degiorgis, M.P.; Ryser, A.; Bacciarini, L.N.; Angst, C.; Gottstein, B.; Janovsky, M.; Breitenmoser, U. Notoedric and sarcoptic mange in free-ranging lynx from Switzerland. J. Wildl. Dis. 2002, 38, $228-232$. [CrossRef] [PubMed]

118. Espinosa, J.; Ráez-Bravo, A.; López-Olvera, J.R.; Pérez, J.M.; Lavín, S.; Tvarijonaviciute, A.; Cano-Manue, F.J.; Fandos, P.; Soriguer, R.C.; Granados, J.E.; et al. Histopathology, microbiology and the inflammatory process associated with Sarcoptesscabiei infection in the Iberian ibex, Capra pyrenaica. Parasites Vectors 2017, 10, 596. [CrossRef] [PubMed]

Publisher's Note: MDPI stays neutral with regard to jurisdictional claims in published maps and institutional affiliations.

(C) 2020 by the authors. Licensee MDPI, Basel, Switzerland. This article is an open access article distributed under the terms and conditions of the Creative Commons Attribution (CC BY) license (http://creativecommons.org/licenses/by/4.0/). 